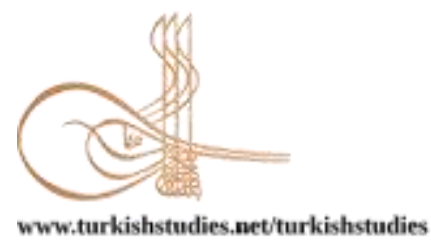

Turkish Studies

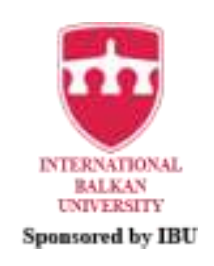

\title{
Mevlevihanelerinin Yeniden İşlevlendirilmesi; Manisa, Galata ve Lefkoşa Mevlevihaneleri Örnekleri"
}

\author{
Re-Functioning Of Mevlevi Building (Mevlevihane), Manisa, Galata and Lefkoşa Mevlevi \\ Buildings Examples
}

\author{
Özlem Atalan**
}

\begin{abstract}
Monumental architectural structures are one of the important elements reflecting the social habits and life relations. At the same time, with their traditional and monumental quality, they are material cultural elements that document the continuity of the society, emphasize its identity and create the memory of the place. Historical environments are areas that carry traces from the past and present natural and cultural works together. Changing life styles, demands and needs throughout the centuries have differentiated the functions and use of historical monumental buildings. Restoration technique, which is applied with the names of refunctioning, renovation, renovation or re-use, allows the reuse of historical buildings. The historical monumental structures lost their original function, being re-used as a cultural heritage, is important in the context of the continuing use of historical structures. In today's conditions where cultural tourism is important, the re-activation of historical buildings has made a great contribution to the cities. However, refunctioning is the most important contribution; both in the preservation of monumental structures and in the maintenance of the identities of the cities. Historical structures, especially the re-functioning of monumental structures, need to be planned in such a way that new functions to be given to the structure will not harm the original qualities of the structure, or even emphasize its features. The reusing of monumental structures of historical and cultural significance makes it possible to use these structures today as well. This scope of work; re-functioning of Manisa, Galata and Nicosia Mevlevi building (Mevlevihane) and their transformation into a museums will be investigated. Mevlevi building is defined as buildings and building groups, where the tendency to maintain good moral values is maintained by using different ceremonies and actions. Different tomb and whirling space or place of worship connections can be seen in the Mevlevihane. Within the scope of this research, the architectural layouts of the Mevlevihane's will be investigated. In this context, refunctioning of Mevlevi buildings and its conservation problems will be examined.
\end{abstract}

Structured Abstract: Changing life styles, demands and needs throughout the centuries have differentiated the functions and uses of historical structures. For example; many historical monumental buildings such as caravanserai, inn, bedesten (covered Turkish bazaar), Turkish bath, and palace are not used today.

\footnotetext{
* Makalenin bir kısmı, 26-28 Ekim 2017 tarihlerinde Uluslararası Manisa Sempozyumunda (Manisa) sunulmuştur. Makale yeniden ele alınarak hazırlanmıştır.

** Doç.Dr., Manisa Celal Bayar Üniversitesi, Kula Meslek Yüksekokulu, Mimarlık ve Şehir Planlama Bölümü, Mimari Restorasyon Programı.

Assoc. Prof. Dr. Manisa Celal Bayar University, Kula Vocational School, Department of Architecture and Urban Planning

ORCID https://orcid.org/0000-0002-9772-1642

oatalan@hotmail.com ozlematalan@cbu.edu.tr

Cite as/ Atıf: Atalan, Ö. (2020). Mevlevihanelerinin yeniden işlevlendirilmesi; Manisa, Galata ve Lefkoşa

Mevlevihaneleri örnekleri. Turkish Studies, 15(3), 1635-1655. https://dx.doi.org/10.29228/TurkishStudies.42174

Received/Geliş: 16 March/Mart 2020

Checked by plagiarism software

Accepted/Kabul: 20 June/Haziran 2020

Published/Yayın: 25 June/Haziran 2020

Copyright $($ ) MDE, Turkey

CC BY-NC 4.0
} 
Functioning of such structures with the new function will allow the structures to be used in today's conditions. The restoration technique, known by the names of "re-functioning, renovation, renovation or reuse", allows the reuse of historical buildings.

This scope of article; re-functioning of Manisa, Galata and Nicosia Mevlevi buildings and their transformation into a museums will be investigated. Within the scope of this research, the architectural layouts of the Mevlevi buildings will be investigated. In this context, re-functioning of Mevlevi buildings and its conservation problems will be examined.

Mevlevi building is defined as buildings and building groups, where the tendency to maintain good moral values is maintained by using different ceremonies and actions. Different tomb and whirling space or place of worship connections can be seen in the Mevlevi building.

Mevlevi building varies according to the "sema" (welkin) sections. The architectural trends that have changed over the centuries have been influential in the development of the schemas of the sema sections. For example, in Yenikap1, Kütahya, Nicosia, Bursa and Manisa Mevlevi building, it is seen in the sema neighborhoods planned in a circular form. However, since unused areas are formed in the square or rectangular plan whirling dervishes, polygon plans were applied and the corners were eliminated.

The whirling section of the Bahariye Mevlevi building was designed with a square plan and the edges were beveled at an angle. Again, at Kasımpaşa Mevlevi Building, the corners are beveled 45 degrees. According to Demiraslan (2014), the whirling houses built before the 17th century was built with a rectangular or square plan. With the 18th century, the welkin sections were planned as polygons or circulars. Circular forms are seen in the 19th century.

Mevlevi buildings vary according to the number of floors. Some Mevlevi buildings are built as single storey. Some whirling dervishes were built on two or three floors. For example, while Cyprus Nicosia Mevlevi building was built with one floor, Manisa Mevlevi building was built with two floors and Galata Mevlevi building with three floors.

Mevlevi buildings generally consist of four main sections. The welkin section; Masjid, Mausoleum, Matbah-1 Şerif (Kitchen) and Dervish cell-spaces compose these sections. According to the plan scheme, Mevlevi building can sometimes be built as an interpretation of the mosque plan. In the Mevlevi buildings, the scheme of a large and wide central structure gathered under a single dome was used. There are various splits added to the main dome space. The main structure is sometimes covered with a single dome and sometimes with different covering systems.

After Afyon Karahisar Mevlevi building, Manisa and Aleppo Mevlevi building are considered as second degree (Tezcan, 1994). Pakalın (1983), on the other hand, ranks its importance as Konya, Manisa and Gelibolu Mevlevi building after Konya. According to both rankings, it is understood that Manisa Mevlevi structure has a very important place among other magazines. In Evliya Çelebi's "Seyahatname" (travel book), there is some information about Anatolian Mevlevi buildings.

Museum and exhibition function was given after the restorations were completed for Cyprus Nicosia, Manisa and Galata Mevlevi Houses. In the buildings, the life model and ceremonies of the Mevlevi sect are explained. In addition, it is seen that object-furniture is exhibited. In the functioning of monumental buildings, the functioning of the building with the least change will support the preservation of the original state of the building. This function, which has been given to the building with minimal intervention, has enabled the building to maintain its original form, while at the same time allowing the building to exhibit itself as a work of art. In this context, the museum function given to the building allows both the preservation of the building and the display of the lost Mevlevi sect.

In this type of monumental buildings; It is important to design the interiors of the buildings to reflect their historical period features, to display the objects belonging to their period and to place information signs to introduce the architecture of the building. Thus, the monumental structure and the authenticity of its interior spaces can be maintained. In this context, the museum function given to the building will allow both the preservation of the building and the display of the lost Mevlevi sect. The objects and works of art in the spaces explain the history and operation of the buildings. The whirling dervish section, suffering section, Matbah-1 Şerif (Kitchen of mevlevi building) section, etc., which have different sections in the Mevlevi buildings. Departments such as may reflect the characteristics of their historical period. 
The re-functioning of the existing cultural heritage is a restoration method that should be applied in our country as in the world. The cultural assets, which have historical value, lose their original function over time, the urban changes and the economic factors that they have undergone, require economic re-functioning. In particular, the re-functioning of monumental structures with historical and cultural significance makes it possible to use these structures today.

As a result, monumental structures are "works of art" that need to be preserved and maintained. Refunctioning of monumental structures supports effective and continuous conservation. These functionalities should be planned in a way that will not spoil the original form of the building, damage the identity of the building, or damage the character of the building with its design and interior furniture. As in the studied Mevlevi building examples, monumental buildings should be re-functionalized and opened for use. In the refunctioning, when the structures cannot be used with their original function, its use as a "museum" to reflect the features of its period can be supported. This function may be the usage model that will require minimal intervention to the structure. In addition, as mentioned earlier, monumental buildings are a work of art. Firstly, "mass integrity and indoor features" should be emphasized in these structures.

Keywords: Architecture, Mevlevihane (lodge used by Mevlevi dervishes, Mevlevi Building), Manisa Mevlevi Building, Galata Mevlevi Building, Nicosia Mevlevi Building, Sufism.

Öz: Anıtsal mimari yapılar, topluma ait alışkanlıkları ve yaşama ilişkilerini yansıtan önemli unsurlardan biridir. Aynı zamanda, geleneksel ve anıtsal niteliği ile toplumun sürekliliğini belgeleyen, kimliğini vurgulayan ve yer belleğini oluşturan, maddi kültür öğeleridir. Tarihi çevreler ise, geçmişten gelen izleri günümüze taşıyan, doğal ve kültürel eserlerin bir arada olduğu alanlardır. Yüzyıllar süresince değişen yaşama biçimleri, talep ve ihtiyaçlar, tarihi anıtsal yapıların işlevlerini ve kullanımını farklılaştırmıştır. Yeniden işlevlendirme, yenileme, renovasyon ya da yeniden kullanım isimleriyle uygulanan, restorasyon tekniği, tarihi yapıların yeniden kullanımına olanak vermektedir. Özgün işlevini yitirmiş anıtsal yapıların yeniden işlevlendirilerek, kültürel bir varlık olarak yaşatılması, tarihi yapıların sürdürülerek kullanılması bağlamında önem taşımaktadır. Kültürel turizmin önem kazandığı günümüz koşullarında, tarihi yapıların yeniden işlevlendirilmesi, kentlere büyük katkıda bulunmaktadır. Bununla birlikte, yeniden işlevlendirme en önemli katkısını; hem tarihi yapıların korunmasında, hem de kentlerin kimliklerinin sürdürülmesinde göstermektedir. Ancak, tarihi yapıların yeniden işlevlendirilmesinde, yapıya verilecek yeni işlevlerin, yapının özgün niteliklerine zarar vermeyecek, hatta özelliklerini vurgulayacak şekilde planlanması gerekmektedir. Bu çalışma kapsamında; Manisa, Galata ve Lefkoşa Mevlevihanelerinin yeniden işlevlendirilmesi ve müzeye dönüşümü araştırılacaktır. Mevlevihaneler "değişik vasıta ve vesileleri kullanarak güzel ahlakı yaşatma eğiliminin sürdürüldüğü tesis ve yapılanmalar" olarak tanımlanmaktadır. Mevlevihanelerde farklı türbesemahane veya türbe- harim bağlantıları görülebilir. Bu yapılar, pek çok defa tamir ve onarım görmüştür. Bu araştırma kapsamında, Mevlevihanelerin mimari düzenleri araştırılacaktır. Bu bağlamda, Mevlevihanelerin yeniden işlevlendirilmesi ve koruma problemleri tartışılacaktır.

Anahtar Kelimeler: Mimarlık, Mevlevihane, Manisa Mevlevihanesi, Galata Mevlevihanesi, Lefkoşa Mevlevihanesi, Sufizm.

\section{Giriș}

Mimari eserler, toplum ait alışkanlıkları ve yaşama ilişkilerini yansıtan önemli unsurlardan biridir. Yüzyıllar süresince değişen yaşama biçimleri, talep ve ihtiyaçlar, tarihi yapıların işlevlerini ve kullanımını farklılaştırmıştır. Örneğin; kervansaray, han, bedesten, hamam, saray gibi pek çok tarihi anıtsal yapı günümüzde kullanılmamaktadır. Bu tür yapıların, yeni işlevle değerlendirilmesi yapıların günümüz koşullarında kullanılabilmelerine olanak sağlayacaktır. Yeniden işlevlendirme, yenileme, renovasyon ya da yeniden kullanım isimleriyle uygulanan, restorasyon tekniği, tarihi yapıların yeniden kullanımına olanak vermektedir. Kuban'ın da (2000) belirttiği gibi bu restorasyon tekniği, anıtsal yapıları ve sivil mimarlık eserleri tekrar bir tasarım süreciyle karşı karşıya bırakmaktadır. Bu sebeple, tarihi yapının, tarihsel önemi, mimari karakteri, kimliği ve yeniden işlevlendirilecek zamana kadar ki kullanımı, yeniden işlevlendirme aşamasında dikkat edilmesi gereken önemli noktalardır. Özellikle, hamam, medrese ya da Mevlevihane gibi anıtsal 
yapıların yeniden işlevlendirilirken bütünlüğünün, tipolojik özelliklerinin ve mekânsal ilişkilerinin bozulmamas1 gerekmektedir (Kuban, 2000; Ahunbay, 1996).

Anıtsal yapılar içinde, Mevlevihaneler de günümüz yaşam tarzı yönüyle bakıldığında işlevsizleşmiştir. Bu sebeple bu yapıların, yeniden işlevlendirmesi gerekmektedir. Önemli anıtsal yapılara, verilecek fonksiyonlar; öncelikle tarihi yapının mimari karakterine, daha sonra kent-yapı mekân ilişkisine ve gereksinimine göre belirlenebilir. Özellikle dini yapıların, mimari karakterine ve eski işlevine saygılı bir şekilde düzenlenmesi gerekmektedir.

Venedik Tüzüğü'nün 3-4-5. Maddesi'nde; “Kültür varlı̆̆ının korunmasında ve onarılmasındaki amaç, onları bir sanat eseri olduğu kadar, bir tarihi belge olarak da korumaktır. Kültür varlığının korunmasındaki temel tutum korumanın kalıcl olması, sürekliliğinin sağlanmasıdır. Kültür varlı̆̆ının korunması, her zaman onları herhangi bir yararlı toplumsal amaç için kullanmakla kolaylaştırılabilir. Bunun için bu tür bir kullanma arzu edilir, fakat bu nedenle yapının planı, ya da bezemeleri değiştirilmemelidir. Ancak bu sınırlar içinde yeni işlevin gerektirdiği değişiklikler tasarlanabilir ve buna izin verilebilir" denilmiştir. $\mathrm{Bu}$ Venedik Tüzügünün bu maddeleri, anıtsal yapıların sürdürülebilir korunmasına ve yeniden işlevlendirmenin gerekliliğine dikkat çekmekle birlikte, "bir sanat eseri olduğu kadar, bir tarihi belge" olarak korunması gerekliliğinin altını çizmektedir.

\section{Çalışmanın Kapsamı ve Yöntemi}

Çalışma kapsamında, müze olarak yeniden işlevlendirilen, Mevlevihane örnekleri incelenmiştir. Aşağıdaki araştırma ve değerlendirmeler yapılmıştır.

- Mevlevihanelerin mimari karakterleri ve değişim süreci araştırılmıştır.

- Manisa, Galata ve Lefkoşa Mevlevihanelerinin tarihsel geçmişi ve mimari karakterleri incelenmiştir.

- Manisa, Galata ve Lefkoşa Mevlevihanelerinin yeniden işlevlendirilmesi ve yeniden kullanımı, koruma ilkeleri bağlamında incelenmiştir.

Yapılan çalışmada, bilgi toplama aşamasında geniş bir literatür çalışması ve daha sonra alan araştırmaları yapılmıştır. Son aşamada, sentez ve karşıllaştırma yapılarak, yapıların korunma olasılıkları tartış1lmıştır.

\section{Mevlevihane Mimarisi; Manisa Mevlevihanesi, Lefkoşa Mevlevihanesi, Galata Mevlevihanesi Örnekleri}

\section{Mevlevihane Mimarisi}

Mevlevihaneler "değişik vasita ve vesileleri kullanarak güzel ahlak yaşatma eğiliminin sürdürüldüğ̈̈ tesis ve yapılanmalar" olarak tanımlanmaktadır. Mevlevihanelerde farklı türbesemahane veya türbe- harim bağlantıları görülebilir (Numan, 2002). Ancak, Mevlevîhâneler genel olarak, dört ana bölümden oluşmaktadır. Semâhâne bölümü, Mescid, Türbe, Matbah-1 Şerîf (Mevlevihane mutfağı) ve Derviş hücreleri, bu bölümleri oluşturmaktadır.

Plan şeması göz önüne alındığında, Mevlevihaneler kimi zaman cami şemasının yorumlanması olarak da inşa edilebilmektedir. Mevlevihane yapılarında, tek kubbe altında toplanan, büyük ve geniş merkezi bir yapının şemasından yararlanılmıştır. Ana kubbeli mekâna eklenen çeşitli bölünmeler bulunur. Ana yapı, bazen tek kubbe ile bazen de farklı örtü sistemler ile kapat1lir. 


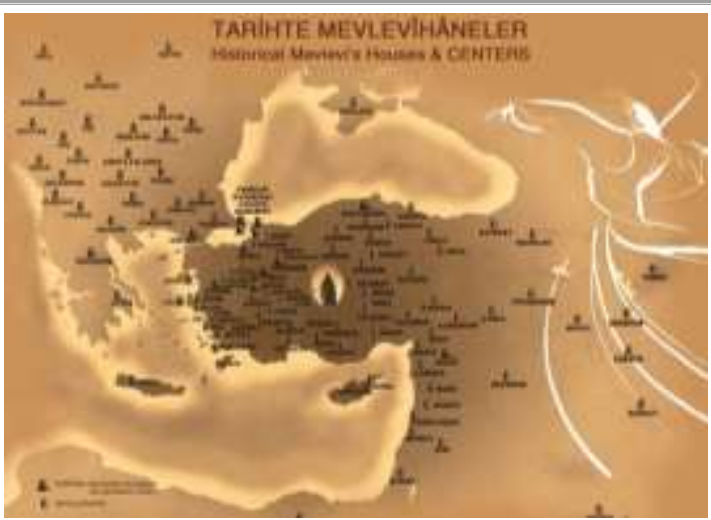

Şekil 1. Osmanl1 Döneminde Mevlevihaneler (URL 1)

Bazı Mevlevihanelerde, türbeler merkezi semahane yapısının dışında tutulmuştur. Örneğin Kütahya Argun Çelebi ve Lefkoşa Mevlevihanelerinde türbeler, merkezi semahane dışında yer alır. Türbe ile bağlantıları zayıftır. Argun Çelebi Mevlevihane'sinde ise, türbeler geniş kemerle, daire plana sahip semahaneye bağlanmaktadır. Anadolu'da olduğu gibi İstanbul'da da, pek çok Mevlevihane vardır. Büyük bir dergâh olan Yenikapı Mevlevihane'sinin plan şeması, birbirinin eşi iki oluşturulmuş parça mekânın kaydırılarak birleştirilmesi ile oluşturulmuştur. Bu iki modülleri oluşturan mekânların biri türbeye, diğeri semahaneye hizmet etmektedir (Numan, 2002).

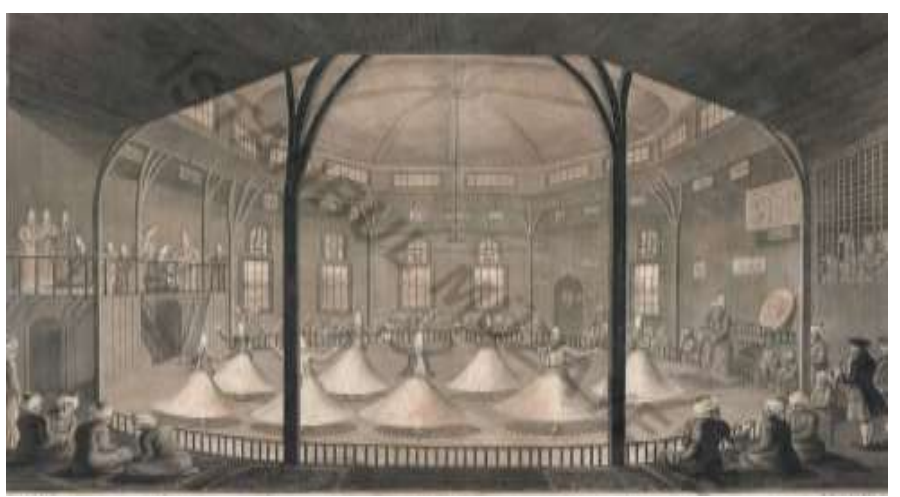

Şekil 2. İstanbul'da Mevlevihane konulu gravür, 1769

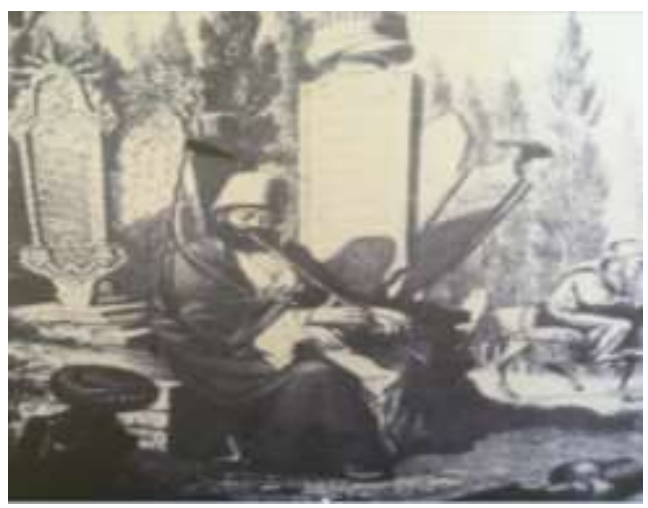

Şekil 3. Brindesi’nin 1860 tarihli Neyzen tablosu (Dayığlu, 2003)

Mevlevihaneler semahanelerine gör farkl1l1klar göstermektedir. Semahanelerin plan şemalarının değişiminde, yüzyıllar boyunca değişen mimarlık akımları etkili olmuştur. Örneğin, Yenikapı, Kütahya, Lefkoşa, Bursa ve Manisa Mevlevihanelerinde dairesel formda planlanmış sema mahalleri görülmektedir. Bununla birlikte, kare veya dikdörtgen planlı semahanelerde, 
köşelerde kullanılmayan alanlar oluştuğu için çokgen planlar uygulanmış ve köşeler ortadan kaldırılmıştır. Bahariye Mevlevihanesi'nin semahanesi kare planlı tasarlanmış, kenarları yumuşatılmıştır. Yine, Kasımpaşa Mevlevihanesi'nde ise köşeler 45 derece pahlanmıştır. Demiraslan'a (2014) göre; 17. yüzyıldan önce yapılan semahaneler dikdörtgen veya kare planlı inşa edilmiştir. 18. yüzyılla birlikte, semahaneler çokgen ya da dairesel olarak planlanmıştır. 19. yüzy1lda dairesel formlar görülmektedir (Demiraslan, 2014).

Mevlevihaneler, yine kat adetlerine göre farklılıklar göstermektedir. Bazı Mevlevihaneler tek katlı olarak inşa edilmişlerdir. Bazı Mevlevihaneler ise, iki ve ya üç katlı inşa edilmişlerdir. Örneğin Kıbrıs Lefkoşa Mevlevihanesi tek katlı inşa edilmişken, Manisa Mevlevihanesi iki katlı, Galata Mevlevihanesi ise üç katlı inşa edilmiştir.

\section{Kullanımı \\ Anadolu'da ve Kıbrıs'ta Yer Alan Bazı Mevlevihanelerin Müze İşleviyle Yeniden}

\section{Kıbrıs Lefkoşa Mevlevihanesi}

Mevleviliğin, Kıbrıs'ın Osmanlı İdaresi’ne girdiği 1571 yılından itibaren, Konya, Kula, Karaman ve Sivas gibi yerleşim birimlerinden gelenler tarafindan, Kıbrıs'a getirildiği düşünülmektedir. Tekke, Osmanlı idaresinde bulunduğu asırlar boyunca Kıbrıs'ın dinî, tasavvufî, sosyal, kültürel ve sanatsal hayatına önemli katkılarda bulunmuştur. Mevleviliğin Anadolu'daki merkezi Konya, Suriye'deki Halep ve Kıbrıs'ta ise Lefkoşa olmuştur. Lefkoşa Mevlevihanesi; Kıbrıs Mevlevîhânesi, Arabahmet Paşa Mevlevihanesí, Ferhat Paşa Mevlevîhânesi, Ahmet Paşa Mevlevîhânesi, Girne Kapısı Mevlevî Tekkesi, Lefkoşa Mevlevî Tekkesi gibi isimlerle anılmaktadır. Arap Ahmed Paşa tarafından 1593-1594 yıllarında inşa ettirilmiştir. Yapı şehrin merkez bölümünde, Girne Kapısı yakınında yer almaktadır. Kıbrıs'ın fethinden sonraki dönemde Mevlevîliğin odak noktası olmuştur (Kaya, 2017; Altan, 2001; Özönder, 2010; Fedai, 2010).

Mevlevihane içinde tekke binası yer almaktadır. Kaynaklarda, yapıda yer alan bu tekkenin 17. yüzyılın başlarında "Emine Sultan" adlı saraylının verdiği arazi üzerine kurulduğu belirtilmektedir. Türbe binalarının kuzey-doğu dış duvarının yanındaki ismi belirtilmeyen mezarın, Emine Sultan'a ait olduğu düşünülmektedir. Tekkenin ilk inşa edildiği dönemde, semahane, türbe, derviş odaları, mutfak, misafir odaları gibi bölümleri vardı. 1873'lü yıllarda ise, tekkede, mesnevi han, şeyh ve dervişlerden oluşan 36 kişi çalışıyordu (URL 2).

1934 y1lında Halep'ten getirilen son şeyh Şamlı Selim Dede'nin 9 Aralık 1953 tarihinde ölmesi ile birlikte Kıbrıs'taki Mevlevilik tarikatı da son bulmuştur. Zaman içinde değişen koşulların etkisiyle mevlevîhânenin derviş hücreleri, mutfağı ve diğer bazı bölümleri 1956 yılında, çocuk yuvası olarak dönüştürülmüştür. Yapılar, 1962 yılında, Etnoğrafya Müzesi olarak restore edilerek yeniden işlevlendirilmiştir. Mevlevîhâne, 2002-2002 yılları arasında restore edilerek, Mevlevî Müzesi olarak kullanılmaktadır (Altan, 2001; Özönder, 2010; Fedai, 2010; Numan, 2002: 126-127).

Mevlevihane'ye giriş kapısının solunda, bir sokak çeşmesi bulunmaktadır. Tekkeye giriş kapısının üst başında "ya Hazreti Mevlana. Ketebe (yazan) Ahmet Burhanettin" cümlesi yazılmıştır. Büyük bir kapıdan sonra, tekkenin avlusuna geçilir. Burada, çoğunluğu tarihi Girne Kapısı Mezarlığı'na ait mezar taşları ve yıkılmış bazı yapıların kitabeleri bulunmaktadır. (URL 2)

Yapı tek katlıdır. Avlunun doğusundaki basık kemerli giriş kapısından semahane bölümüne geçilmektedir. Bina içinde, Mihrap, sema ayinlerinin düzenlendiği bölüm, ahşap mutrib mahfili ve mutfak mekânları yer almaktadır. Semahane'nin güney-batısındaki kapıdan altı kubbeyle örtülü olan türbe bölümüne girilmektedir. Bu bölümlerde, Mevlevi ileri gelenlerine ait 16 mezar yer alır. Kemerlerle türbe bölümleri birbirine bağlanmaktadır. Türbelerin sonuncusunun dışa açılan kapısı ile dışarı çıkılmaktadır. 

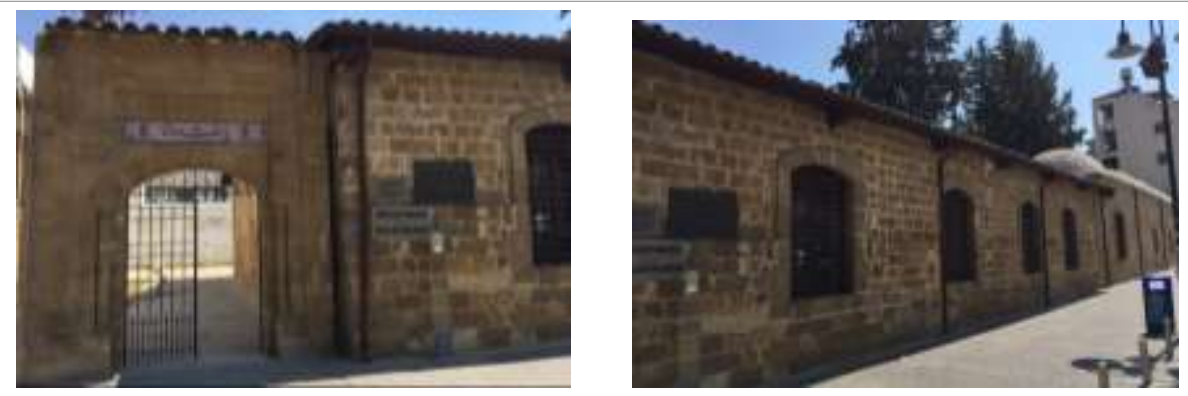

Şekil 4. Şekil 5. Lefkoşa Mevlevihanesi Ön Cephesi, (KKTC, 2018)
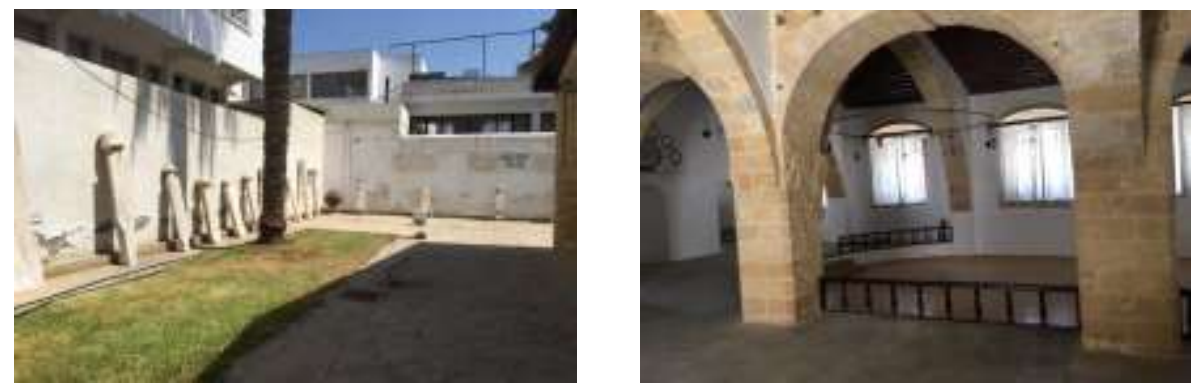

Şekil 6. Lefkoşa Mevlevihanesi iç bahçesi (KKTC, 2018)

Şekil 7 . Lefkoşa Mevlevihanesi semahane bölümü (KKTC, 2018)
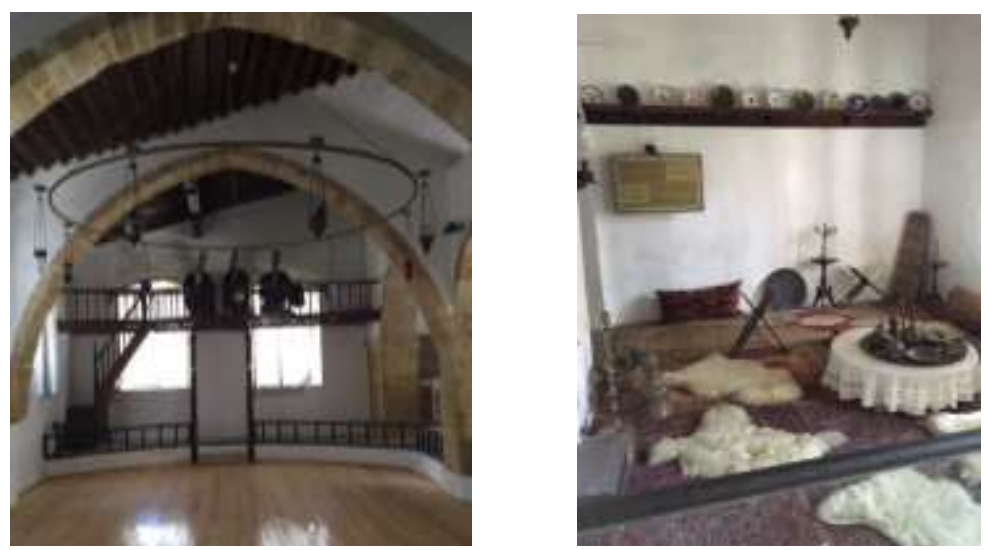

Şekil 8. Lefkoşa Mevlevihanesi Semahane Bölümü, (KKTC, 2018) Şekil 9 . Lefkoşa Mevlevihanesi odaları (KKTC, 2018)
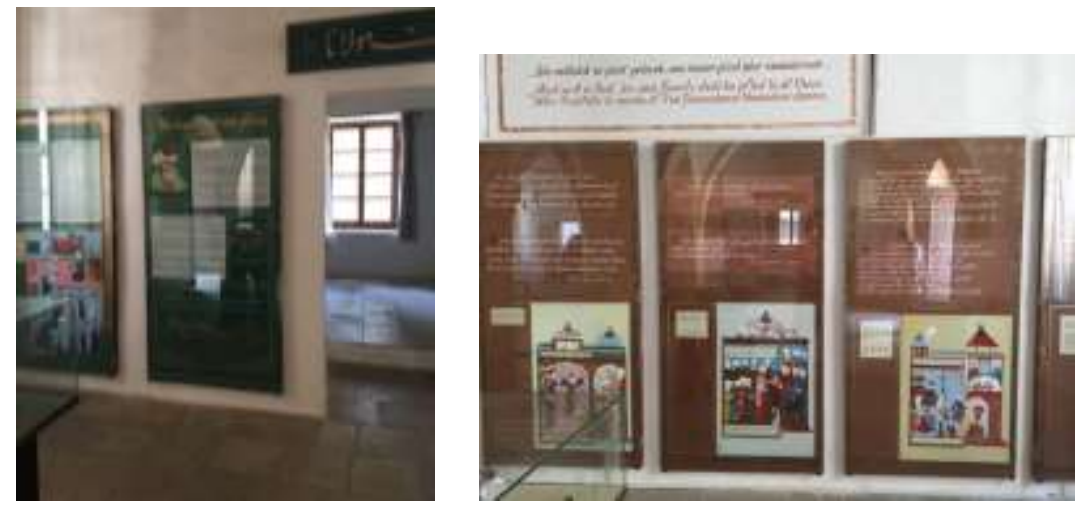

Şekil 10 . Kıbrıs Lefkoşa Mevlevihanesi Sergi Mekânları, (KKTC, 2018) Şekil 11 . Kıbrıs Lefkoşa Mevlevihanesi Sergi Mekânları, (KKTC, 2018) 

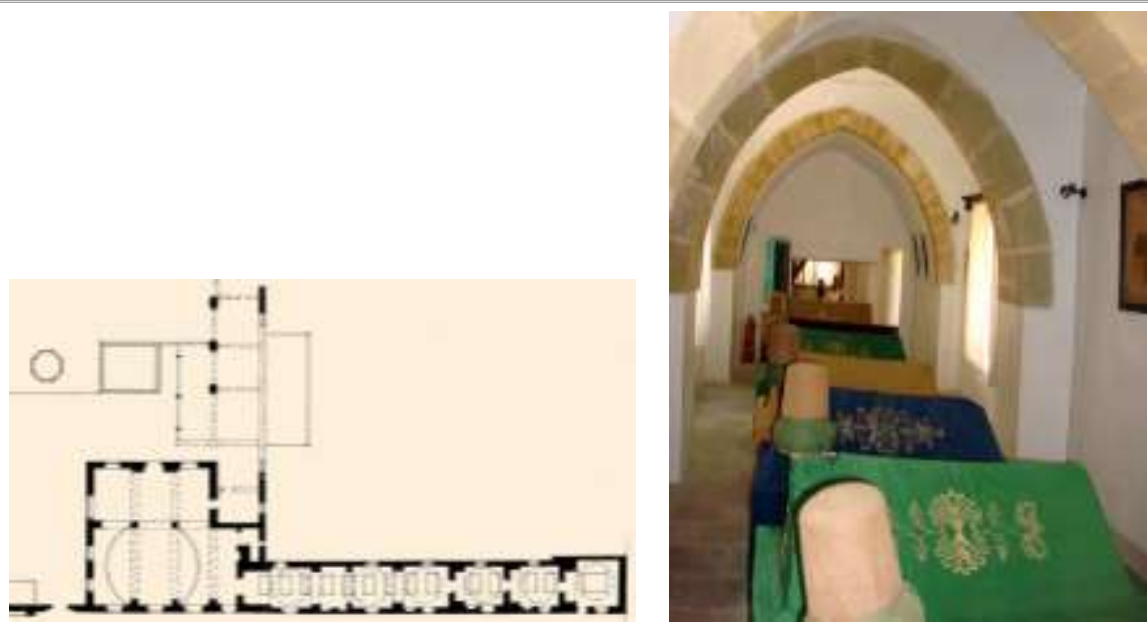

Şekil 12 . Kıbrıs Lefkoşa Mevlevihanesi Planı (URL 2)

Şekil 13 . Kıbrıs Lefkoşa Mevlevihanesi Türbe Bölümleri (KKTC, 2018)

\section{Manisa Mevlevihanesi}

Manisa'da kentleşme için yapılan uygulamalar Saruhan Bey tarafından başlatılmış, Çarşı Mahallesi'nde bir mescit, Çaprazlar Mahallesi’nde bir çeşme ve Gediz üzerinde bir köprü yaptırmışıtır. Muzaffereddin İshak Bey zamanında (1365-1390), Manisa pek çok kurumları ile kale dişında büyüyen bir kent olmuştur. Bu dönemde inşa edilen Ulu Cami; dini, eğitici, sosyal ve kültürel hizmetler veren bir külliye olarak yapılmıştır. Vakviye ve sicil kayıtlarına göre; iki mescit bir zaviye bir han ve iki çeşme ile Mevlevihane İshak Bey zamanında yapılmıştır. Manisa Mevlevihane'si, Yukarı Tabakhane Mahallesi'nde, Milli Park içerisinde yer almaktadır. Yapının kitabesinde, Saruhan Bey'in torunu İshak Çelebi tarafından, 1368-1369 yıllarında yaptırıldığı yazmaktadır. Yapı, aynı zamanda, Ulu Cami Külliyesi'nin bir bölümü içerisindedir. Bu külliye, Emetullahoğlu'nun eseridir (Atalan, 2017; Acun, 1999, s.350).

Afyon Karahisar Mevlevihane'sinden sonra ikinci derecede Manisa ile Halep Mevlevihane'si sayılmaktadır (Tezcan, 1994). Pakalın (1983) ise önem sıralamasını Konya'dan sonra İstanbul, Manisa ve Gelibolu Mevlevihaneleri olarak yapmaktadır. Her iki sıralamaya göre öteki dergâhlar arasında oldukça önemli bir yeri olduğu anlaşılmaktadır. Evliya Çelebi'nin Seyahatname'sinde Mevlevihane'ye ilişkin bir iki küçük bilgi bulunmaktadır. Evliya Çelebi Manisa'daki ünlü gezi yerlerini anlatırken, bunlar arasında "Mevlevihane Bağı" bölgesinin adı geçmektedir. Ayrıca Evliya Çelebi, Manisa ilinde Mevleviliğin yaygınlığından da bahsetmektedir.

Evliya Çelebi’ni yazdığına göre ise 1369 yılında İshak Çelebi tarafından yaptırılan bir tekkedir. Emet Bin Osman adlı mimarın projesine göre yapılmıştır. Evliya Çelebi, Mevlevihane'nin şehrin doğusunda, yüksek bir tepe üzerinde (Manisa -Spil dağının kuzey eteğinde ) olduğunu belirtmektedir. Çelebi, yapı içinde bir semahane ile çok sayıda derviş hücresi bulunduğunu, eski bir kiliseden çevrildiğini anlatmıştır. Ayrıca tüm şehrin buradan göründügünü, güzel ve havadar bir yerde bulunduğunu ve orada pek çok dervişin yaşadığını belirtmiştir (Çelebi, 1935). Günümüzde, şehir kuzeye doğru genişlemiş, Mevlevihane şehrin güneydoğusunda kalmıştır. Mevlevihane'ye ait elde bulunan en eski bilgi Evliya Çelebi'nin Seyahatnamesinde anlattığı kitabeye dayanmaktadır. Bu kitabe, Evliya zamanında giriş kapısında yer almıştır. Günümüzde ise, tamamen kaybolmuştur. Ancak Çelebi aşağıdaki Osmanlıca kitabenin bulunduğunu belirtir (Çelebi, 1935). 

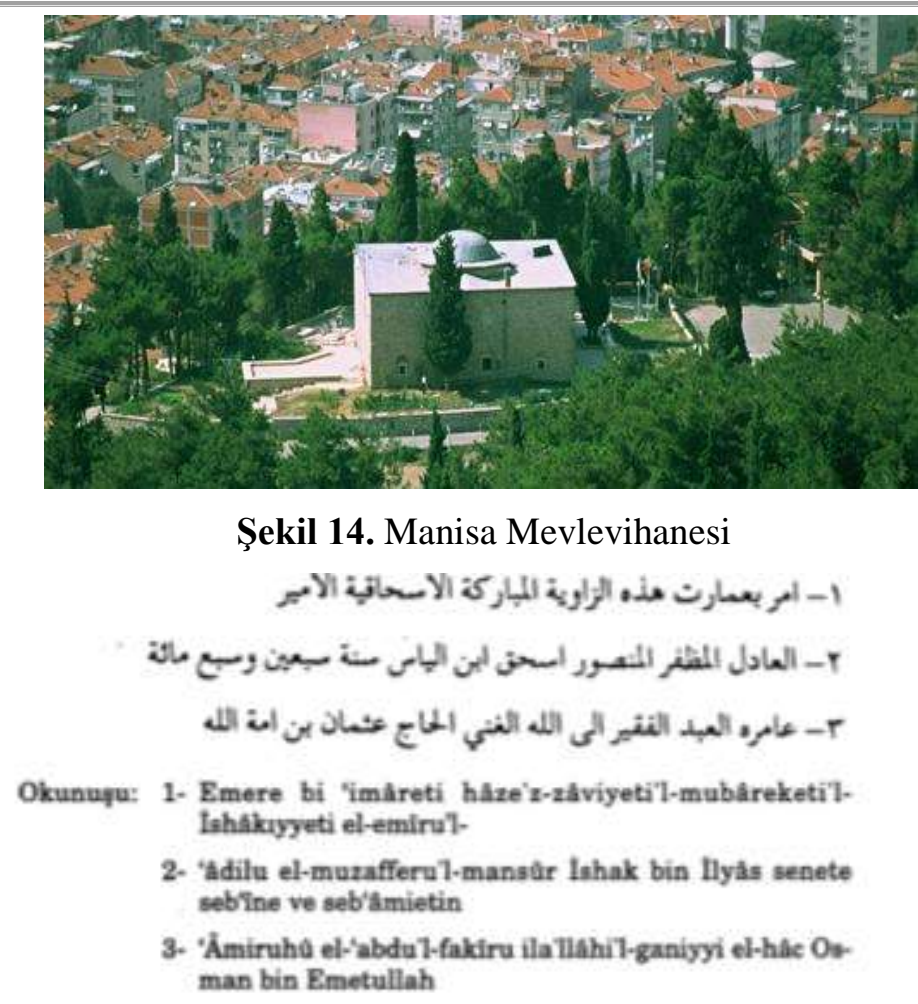

Şekil 15. Kitabe ve okunuşu, (Tanrıkorur, 1995).

Türkçe'ye çevrildiğinde şunlar yazılıdır. "Adil bir emir olan, mansur ve muzaffer Illyasoğlu Ishak, 770 senesinde bu mübarek İshakkiyye Zaviyesi'nin yapılmasını emretti Mimarı gani olan Allah'in fakir kulu Emetullahoğlu Hacı Osman'dır' (Tanrıkorur, 1995).

Uluçay (1940), Mevlevihane'nin mimarının gerçekten Osman bin Emet olduğu konusunda kuşkular bulunduğu anlatmaktadır. Zira Evliya Çelebi'nin bu adı ters yazmış olabileceğini belirtir. Doğrusunun Manisa'daki Ulu Cami’nin mimarının Emet Bin Osman olabileceği belirtilir. Bu isim Ulu Caminin günümüzde yer alan kitabesi üzerinde yazılıdır. Her iki yapının aynı zamanda yapıldığı düşünülürse aynı mimar tarafında yapıldığı düşünülebilir. Fakat, Köklü (1984) babaların oğullarına kendi babalarının isimlerini verdiğini belirterek, Çelebi'nin doğru yazmış olabileceğinin altını çizmektedir.

Mevlana'nın vefatından sonra Mevlevilik bir tarikat yapısını alarak Anadolu'da yayılmıştır. Manisa Mevlevihanesi, etkileyici sağlamlıktaki yapısıyla, dervişliğin kapalı düzenini yansıtan önemli bir binadır. Bu yapı, Anadolu' da orijinal yapısı korunabilmiş, en eski Mevlevihane olarak değerlendirilmektedir. Mevleviliğin iyice benimsendiği İshak Bey Dönemi'nde Ulu Cami ve külliyesi onunla beraber Mevlevihane şehrin yüksek bir noktasına inşa edilmiştir. Vakfiyelerden alınan bilgilerde Mevlevihane'de 10 kişi görev yapmaktaydı. Bu kadrosu ve mutfağı ile şehir dışında olmasına rağmen, şehir içi zaviyesi gibi çalışmaktaydı. Yapılan törenlere göre, şehirden müritler de katılıyorlardı. Şehir dışından gelenler ise konaklayıp mutfaktan yararlanabiliyorlardı. Mesnevi okunuyor ve bunu üzerine konuşuluyordu. Bu dersler, Saruhanoğlu döneminde olduğu gibi Osmanlılar Dönemi'nde de sürdürüldü. Mevlevihane'nin Ulu Cami ile arasının uzak olmasından ötürü, burada daimi olarak cemaatin bulunduğu düşünülmektedir. Yapının mescit görevi gördüğü ve beş vakit namaz kıldırıldığı söylenebilir (Emecen, 2006).

Yap1, pek çok defa tamir görmüştür. Eski kayıtlara göre, 1664-1665 yılında, 1681'de başlayıp 1693-94'lere kadar süren onarımlar geçirmiştir. Mevlevihane, 1960'larda ve 1982'de Vakıflar Genel Müdürlügü tarafından onarım görmüştür. 1999-2002 yılında yeniden restore 
edilerek, müze işleviyle kullanılmaya başlanmıştır. Uluçay ve Gökçen (1939)'e göre yapı, 1960'larda Vakıflar Genel Müdürlüğü tarafından onarılmıştır. Acun ( 1999 ) bu dönem onarımında, sadece yapının dış cephesinin onarıldığını yapının, içinin bakımsız olduğunu anlatmaktadır. $\mathrm{Bu}$ süreçte yapı kullanıma kapalı tutulmuştur. Manisa Mevlevihane'sinin çevresinde, eski mezar kalıntıları ve Manisa Tarzan'ı diye tanınan 1963'te ölen Ahmet Bedevi'ye ait mezar yer almaktadır (Uluçay \&Gökçen, 1939).
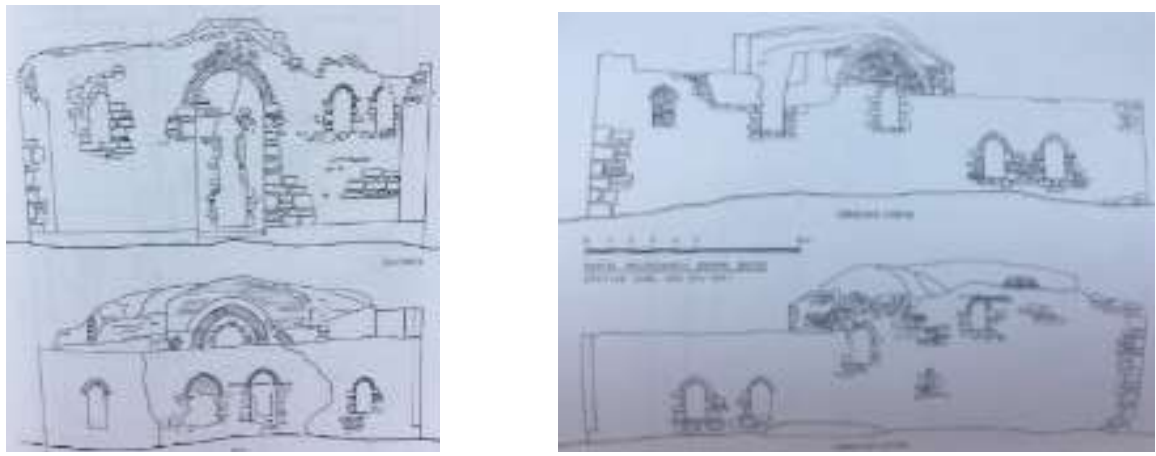

Şekil 16. Restorasyon öncesi Rölöve çizimleri Şekil 17. Restorasyon öncesi Rölöve çizimleri (Köklü, 1984'den, Acun, 1999, Atalan, 2017
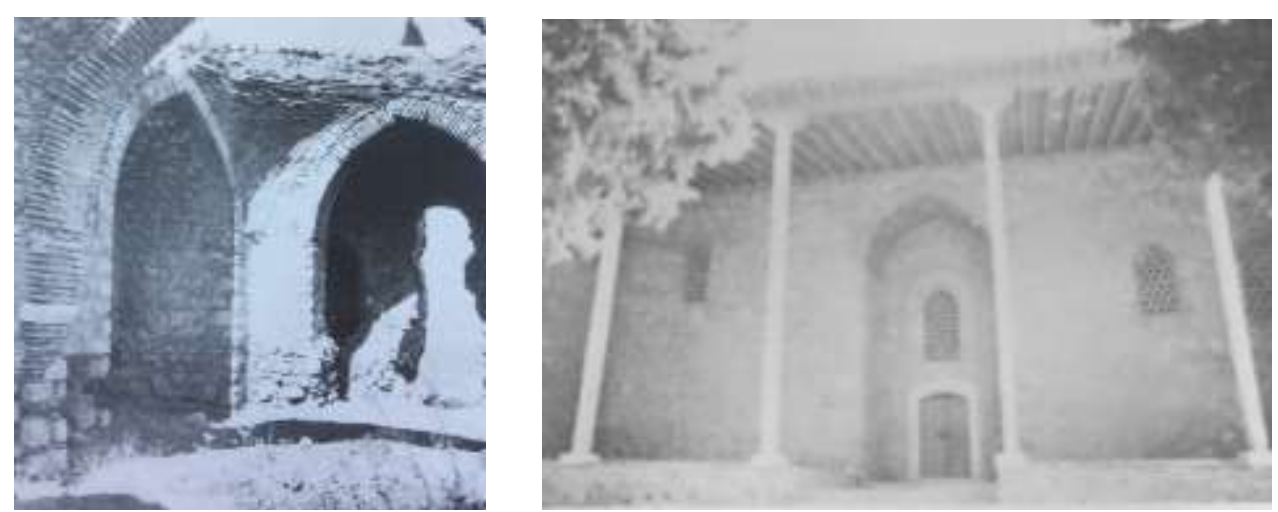

Şekil 18. Restorasyon öncesi (1960 öncesi) Mevlevihane (Acun, 1999) Şekil 19. 1960 Restorasyonu sonrası Mevlevihane (Acun, 1999)
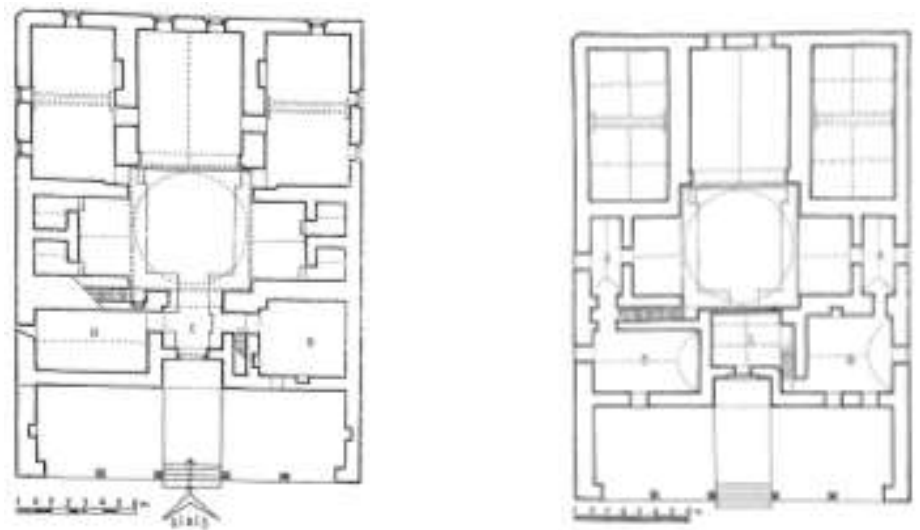

Şekil 20. Mevlevihane zemin kat planı, Şekil 10. Mevlevihane 1. kat planı restitüsyon çizimleri (Köklü'den (1984), Acun, 1999) 


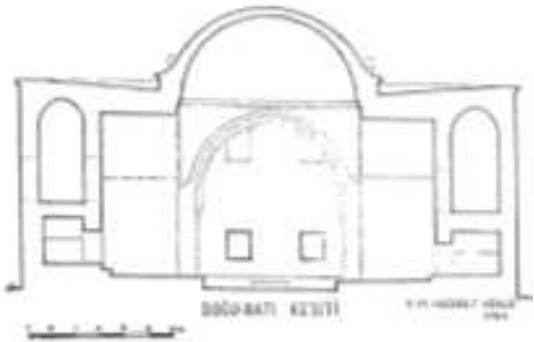

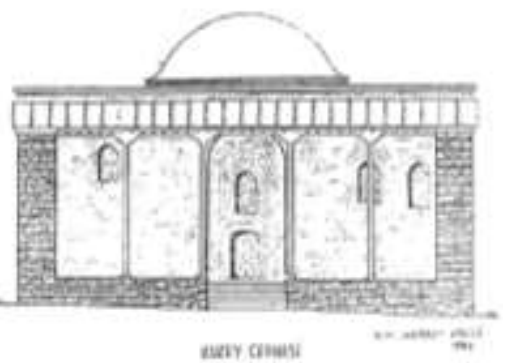

suy conesi

Şekil 21. Mevlevihane doğu batı kesiti Şekil 22. Mevlevihane doğu batı kesiti ve ön görünüş ( Köklü'den (1984), Acun, 1999)
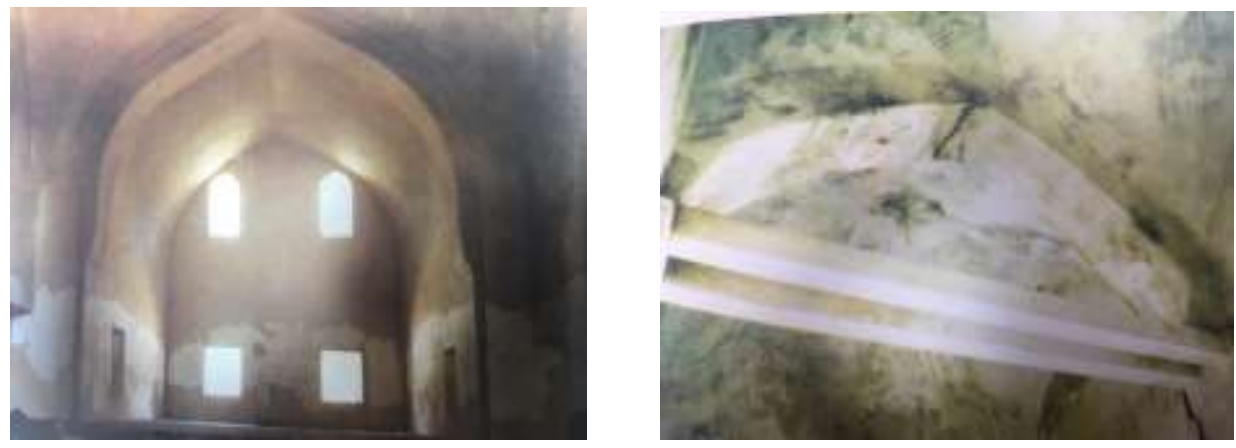

Şekil 23. 2002 Restorasyonu öncesi giriş bölümü iç görünüş (Acun, 1999)

Şekil 24. 2002 Restorasyonu öncesi kemer iç görünüş (Acun, 1999)
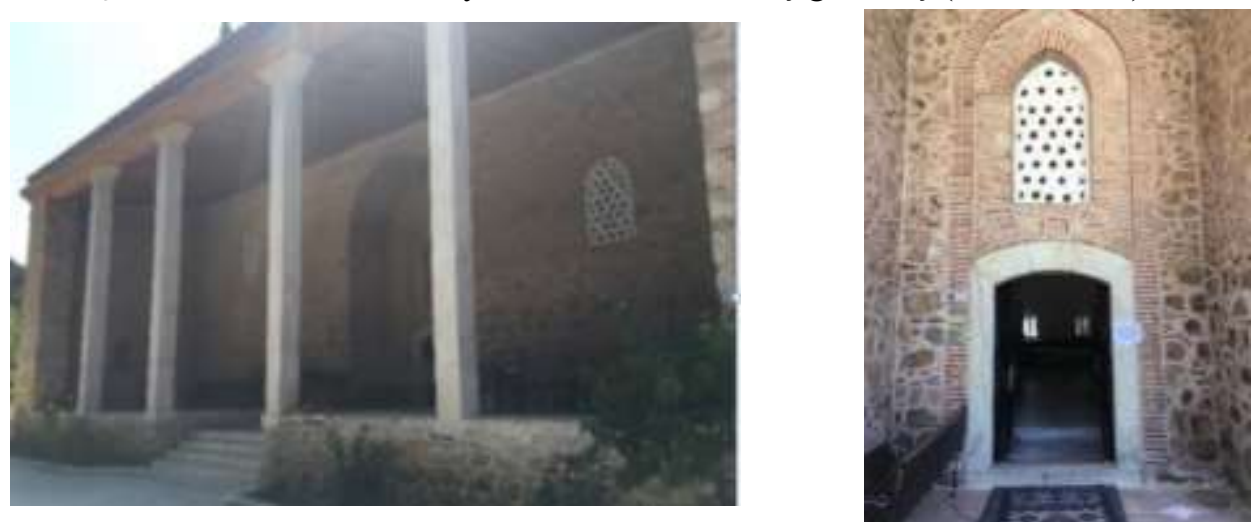

Şekil 25. Mevlevihane ön cephesi (2017) Şekil 26. Mevlevihane kapısı ve Mevlevihane'nin sivri kemerli penceresi

Manisa Mevlevihane'si 14. yüzyıl Osmanlı Mimarisi özelliklerini taşıyan ve orijinal özelliklerini korumuş önemli bir yapıdır. Yap1 ortada küçük bir kubbesi bulunan düz çatılı bir binadır. Plan şeması olarak kareye yakın bir dikdörtgen yapının girişi kuzeyde yer almaktadır. Yerden birkaç basamakla çıkılan teras üzerinde yer alan giriş kapısı yanlardan duvarla çevrilmiştir. $\mathrm{Bu}$ terasın üzerinde, son yıllarda yapılmış beton direkler üzerine oturan bir sundurma bir saçak yer almaktadır. Yapı ortada semahanesi olan dört eyvanlı plan şeması düzenindedir. İç mekân düzeni açısından, kapalı avlulu olan iki katlı bir Mevlevihane özelliği taşımaktadır. Yapının aydınlanmasında kuzey-güney, doğu-batı yönlerinde yer alan pencereler önemli rol oynarlar. Mevlevihane'nin ana bölümü olan, semahanenin bulunduğu kubbeli mekân kuzey-güney ekseninde simetriktir. Arıca semahanenin güneyinde ana eyvan ve ana eyvanın iki yanında derin iki oda yer almaktadır. 


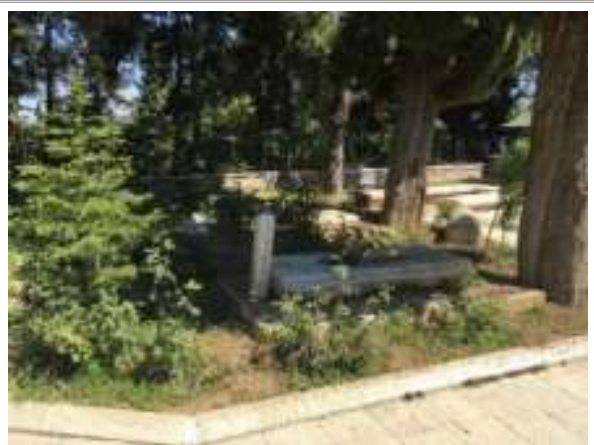

Şekil 27. Mevlevihane'nin hazire bölümü (2017) (2017)

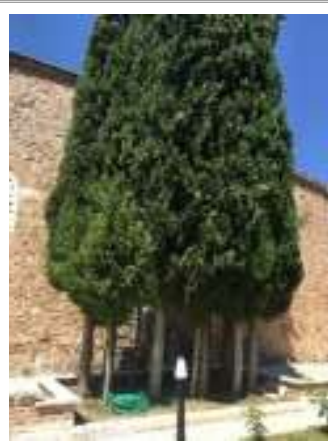

Şekil 28. Mevlevihane'nin yan cephesi,

Mevlevihane'nin semahanesinin iki yanında doğu ve batı eyvanlanı yer almaktadır. Bu bölümler derviş olma aşamasında vakit geçirilen "Çilehane" olarak kullanılan bölümlerdir. Bu bölümler küçük ve iki katlıdır. Yapının giriş kısmında, semahanenin önünde küçük bir giriş eyvanı yer almaktadır. Giriş bölümünün iki yanında yer alan odalar vardır. Girişe açılan bu oda ile giriş bölümü arasında üst kata çıkan bir merdiven yer alır. Yine giriş bölümünün batısında giriş bölümüyle semahanenin batısında yer alan eyvan arasında bir merdiven daha yer alır. $\mathrm{Bu}$ merdivenler U plan şemasını anımsatan düzende birbirine açılan mekânlara bağlanırlar. Üstleri ise çapraz tonozlu çatılarla örtülmüştür.

Mevlevihane yapısı moloz taş ile kemerler, kubbe ve tonozlarda tuğla olmak üzere yığma yapım sisteminde inşa edilmiştir. (1999) göre, Manisa Mevlevihane'si, beşik tonozlu yapı özelliği ve plan yakınlığg ile hemen hemen aynı zamanda yapıldığı sanılan Bursa Hüdavendigar Camisi plan şemasını andırmaktadır.

Manisa Mevlevihanesi'si günümüzde müze işlevine sahiptir. Yapının mekânları; semahane, mescid, matbah-i şerif, hücreler (çilehaneler), şeyh odası ve kiler, mutfaktır. Mevlevihane olarak kullanıldığı dönemlerde, yapıya ritüel gereği sağ ayakla girilir ve çıkılırdı. Mescit mekânı, 5 vakit namaz ve dua için kullanılmaktadır. Matbah- şerif, mutfaktır. Şerefli mutfak demektir. Bu mekânda, günde iki defa kuşluk ve ikindi vaktinde olmak üzere yemek pişirilmekteydi. Kap1 girişinde ise yeni gelen derviş adayı için bekleme yeri olan saka postu yer alır. Yeni gelen bu kişiye Nev-niyaz denir. Bu alanda aday dizlerinin üzerinde üç gün bekletilirdi. Çilehane bölümüne, ruhsal ve bedensel dünyevi zevkten arınma amaçlı girilirdi. Tilavet bölümü okuma bölümüdür. Eğitim amaçlı dini bilgiler, tasavvuf, astronomi, tıp, fizik gibi tüm bilimler öğretilirdi. Semazen başı, 24 saat asma katta, tasavvuf müziği çalardı (Acun, 1999). Günümüzde bu mekânlar tarihsel süreçte kullanımını yansıtacak şekilde, model dervişlerle beraber maket ve objelerle sergilenmektedir.
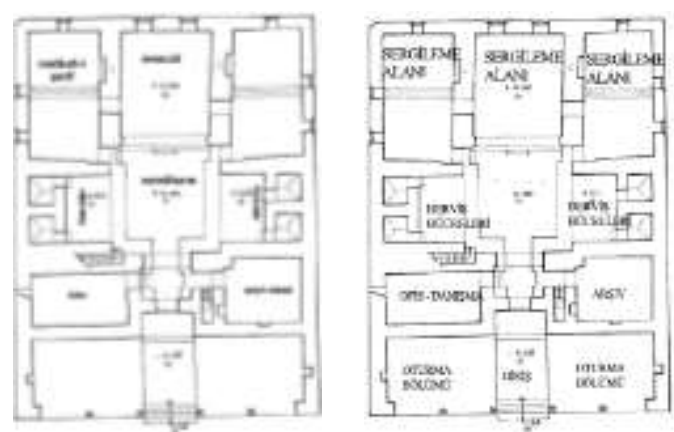

Şekil 29. Mevlevihane mekân bölümleri Şekil 30. Restorasyon sonrası mekânlara verilen işlevler (Acun, 1999'da alınan çizimler tekrar düzenlenmiştir.) 

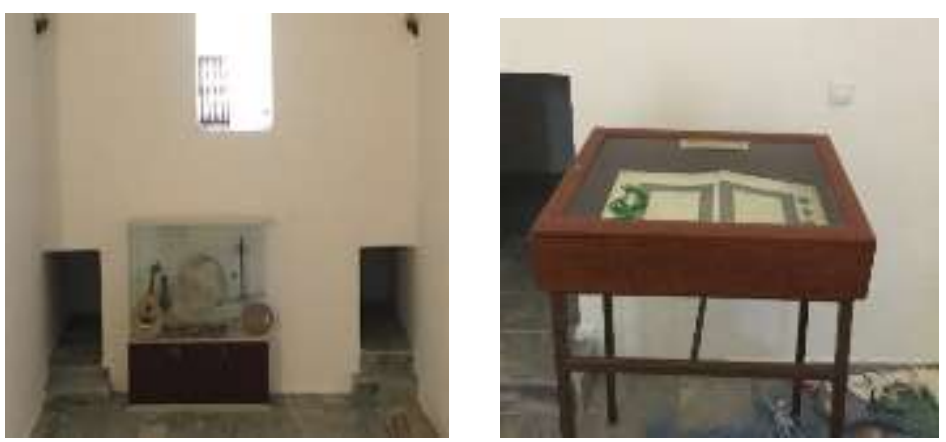

Şekil 31. Mevlevihane'de sergilenen eserler, Şekil 32. Mevlevihane'de sergilenen eserler (2017)
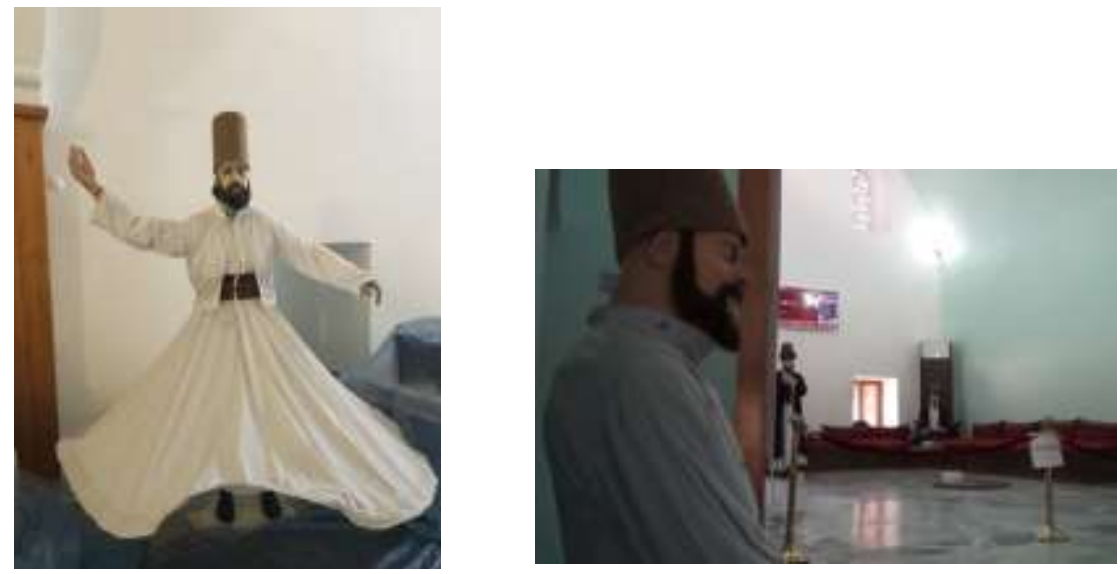

Şekil 33. Mevlevihane'de sergilenen eserler, Şekil 34. Mevlevihane'de sergilenen eserler(2017)
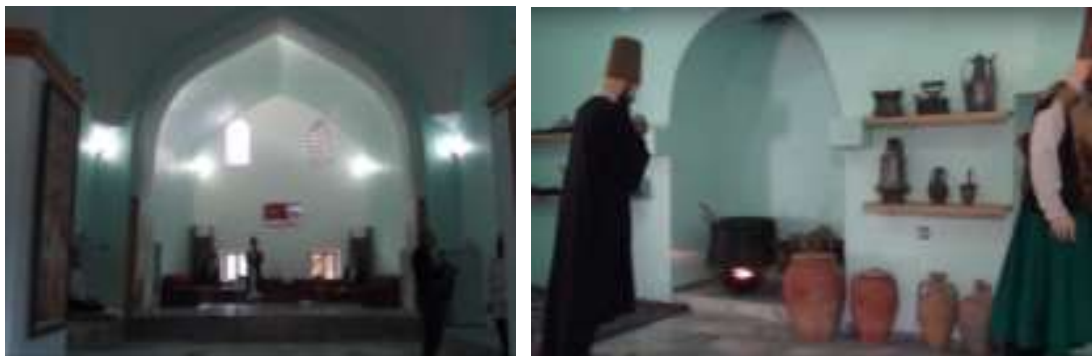

Şekil 35. Mevlevihane'de sergilenen eserler, Şekil 36. Mevlevihane'de sergilenen eserler (2017)

\section{Galata Mevlevihanesi}

İstanbul'da yer alan önemli Mevlevihanelerden biri Galata Mevlevihane'sidir. Galata Mevlevihanesi Fâtih Sultan Mehmed ve II. Bayezid devri devlet adamı İskender Paşa tarafından 1491 yılında kurulmuştur. Bir diğer ismi "Kulekapısı Mevlevîhânesi” dir. Yüzyıllar süresince çeşitli dönemlerde çeşitli eklerle genişletilmiş ve tarikat külliyesi haline çevrilmiştir. Yapının, İskender Paşa'ya ait av çiftliğinin üzerine ve daha önceki yüzyıllara ait H. Theodoros Manastırı'nın kalıntıları üzerine inşa edildiği düşünülmektedir (İslam Ansiklopedisi, 1996). 

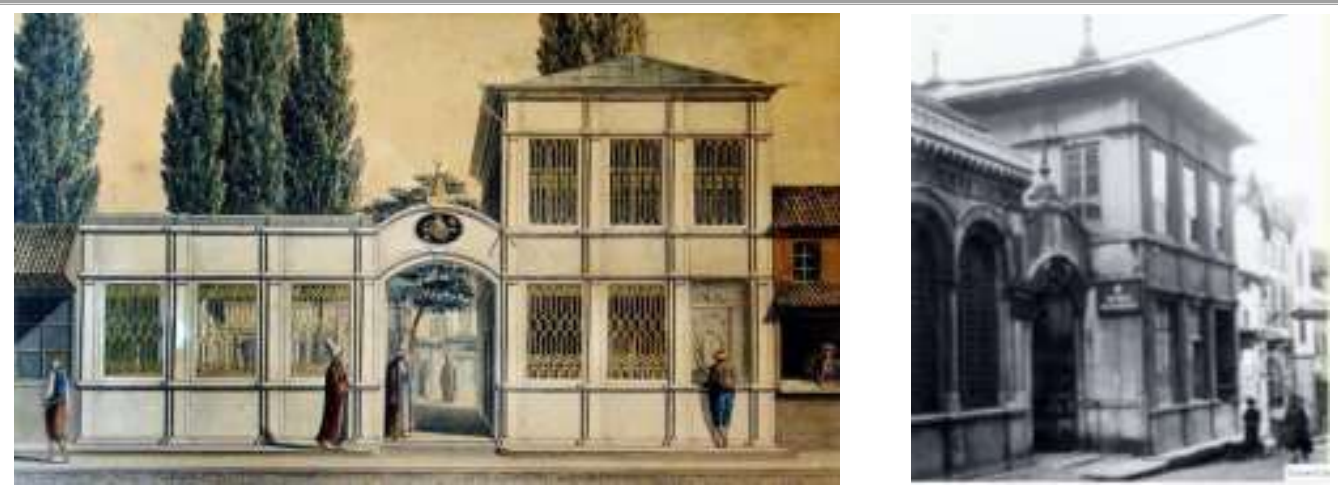

Şekil 37. Galata Mevlevihanesi Gravürü

Şekil 38. Galata Mevlevihanesi

(Dayığlu, 2003, URL 2)

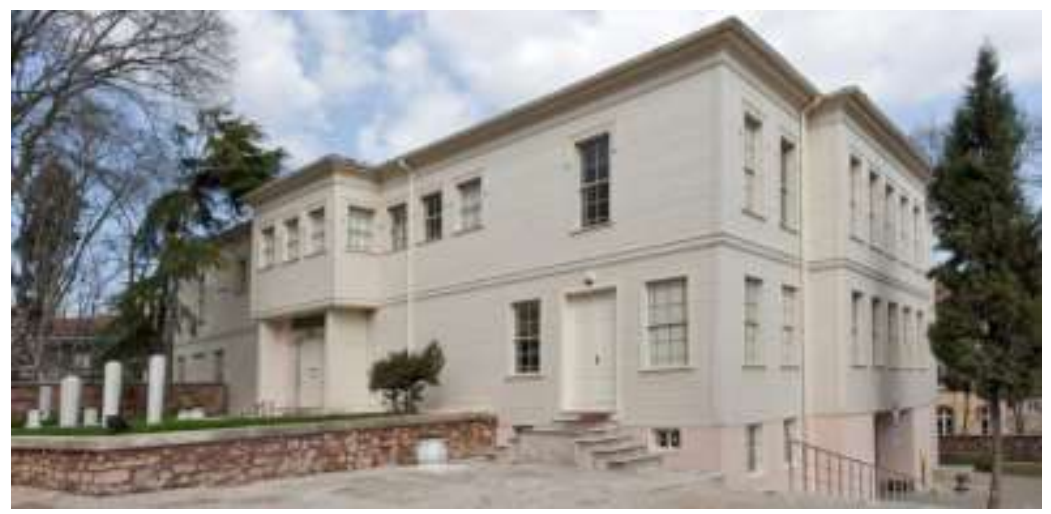

Şekil 39. Semahane (URL3)
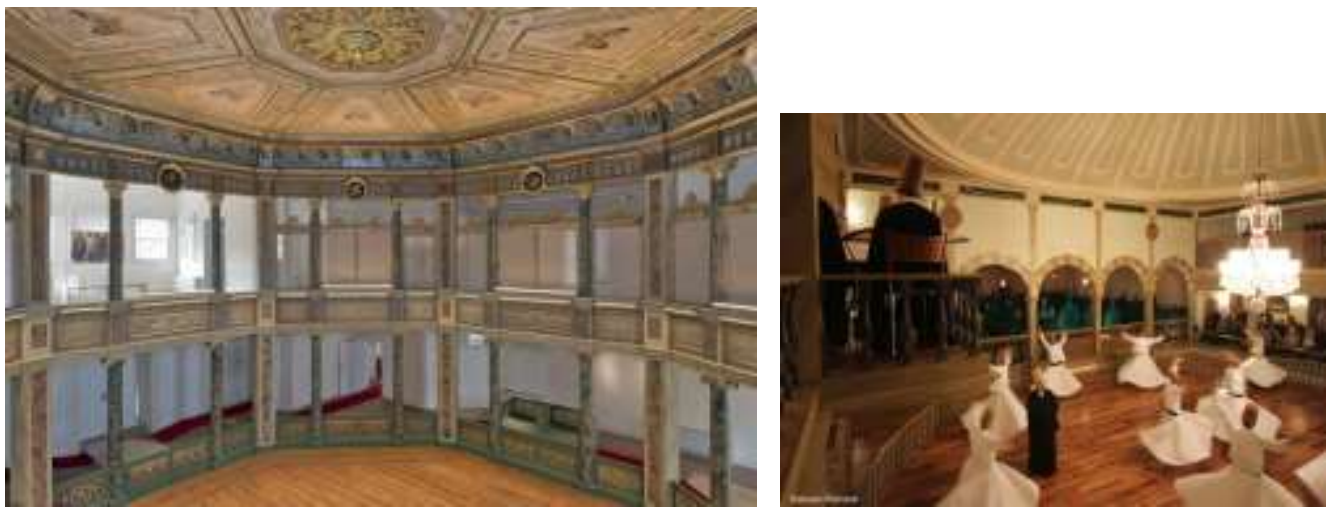

Şekil 40. Galata Mevlevihanesi iç mekânı, (URL3) Şekil 41. Galata Mevlevihanesi Sema Gösterisi (URL3)

1509 depreminde Galata Mevlevîhânesi'nin de hasar gördügü düşünülmektedir. Yapı, dördüncü postnişin' ${ }^{1}$ Mesnevîhan Mahmud Dede'nin (ö. 955/1548) vefatından sonra bakımsız kalarak zarar görmüştür. Önce Halvetî zâviyesi, daha sonra da medrese işlevlendirilen yap1, 1608 yılında büyük bir onarım gerçekleştirmiştir. Mevlevîhânede, 17. yüzyılın ilk yarısında çeşitli onarımlarda bulunulmuştur. 1179 (1765) yılında çıkan Tophane yangınında zarar görmüş ve padişah 3. Mustafa yapıyı yeniden inşa ettirmiştir. Yine, III. Selim de 1206'da (1791-92)

\footnotetext{
${ }^{1}$ Postnişin, tarikatlarda, dergâhta posta oturan, yani o dergâhın başında bulunan şeyhe verilen isimdir. Postnişin olan kişi o tarikatta merkezi otorite hükmündedir. Onun destur verdiği, vekalet verdiği halifeleri vardır. O vekiller dergâhta olabileceği gibi postnişinin işaret ettiği coğrafi bölgelerden de gönderilmiş olabilmektedir.
} 
mevlevîhâne binalarını yenilemiştir. Diğer Mevlevihanelerden farklı olarak, semâhâne'ye bir hünkâr mahfili eklenmiştir (İslam Ansiklopedisi, 1996).

19.yüzyılda Sultan II. Mahmud (1784 - 1839) döneminde 1819 ile 1835 yıllarında, Sultan Abdulmecid (1823 - 1861) döneminde 1851 ile 1859 yıllarındaki imar faaliyetleriyle Mevlevihane son şeklini almıştır. Galata Mevlevîhânesi, doğal alanlarla ve korularla kaplı olan çevresi zaman içinde yerleşime açılmıştır. 19. yüzyılda ise, Pera'daki kâgir Levanten mahalleleri içerisinde kalmıştır. İstanbul'u gelen ve önemli elçilik binaları ve otellerin bulunduğu Pera'da kalan turistlerin sık sık mevlevi törenlerini izlemeye geldiği bir yapı haline gelmiştir.

1925 yılında, Tekke ve zaviyelerin kapatılmasından sonra, ana bina halkevi, girişteki sebilküttab ise karakol olarak kullanılmıştır. Mevlevîhânenin 1946'da bütün birimleriyle bir Mevlevî kültürü müzesine dönüştürülmesi kararı alınmış, "Divan Edebiyatı Müzesi” adıyla 27 Aralık 1975 açılmıştır. Semahane binasında gerçekleşen "Müze Teşhir Tanzim ve Çevre Düzenlemesi" ile müze işlevi almış olan Galata Mevlevihanesi, 21 Kasım 2011'de tekrar düzenlenerek kullanılmaya başlamıştır (Özdemir, 2018).

$\mathrm{Bu}$ süreçte, Mevlevihanenin bahçesinde bulunan Şeyh Galip Türbesi ve Halet Efendi Türbeleri ziyaretçilere açılmıştır. Müze amaçlı, sergi bölümleri, Semahane binasında planlanmıştır. Günümüzde Galata'da, Galipdede Caddesi üzerindeki Mevlevihanenin ana kapısından girilince, orta avludan sonra Semahane binası yer almaktadır. Semahane, ahşap bir konağı anımsatan mimarisi ile diğer Mevlevihane şemalarında farklı tutulmuştur. Semahane yapısı, Sema alanı, alt katta Derviş Odaları ile üst kat mahfiller olmak üzere üç katlı bir plandan oluşmaktadır. Yapının sol bölümünde, Bacılar Dairesi adı verilen Kadınlar Maksuresi, üst katlarda ise mahfiller yer almaktadır. Numan (2002)'a göre Manisa Mevlevihanesi gibi şehir ve yerleşimlerden uzak yapılarda farklı plan şemaları görülebilirken, İstanbul'da yer alan Mevlevihanelerin plan şemalarının daha sıkışık, kat adedinin daha fazla olduğu görülmektedir.

Semâhâneyi, şeyh dairesini (selâmlık) ve dedegân hücrelerini içeren bölümler pek çok kereler onarım ve restorasyon geçirmiştir. Galata Mevlevihanesi'nin 1491'deki ilk hali Tanman'ında belirttiğine göre (1996) tespit edilememektedir. Ancak yapı, döneminin yabanc1 gezgin veya seyyahlarının gravür ve yağlı boya eserlerine göre değerlendirildiğinde, 17. yüzyıl özellikleri göstermektedir. Bu eserlerden görülebildiği üzere, semâhânenin 1608'li yıllardan bugüne kadar, plan şeması ve strüktürel sistemi ile aynı tasarıma sahip olduğu belirtilebilir. Süsleme detaylarında ise döneminin özelliklerine göre farklı stillerde restore edilmiştir (Tanman, 1996).
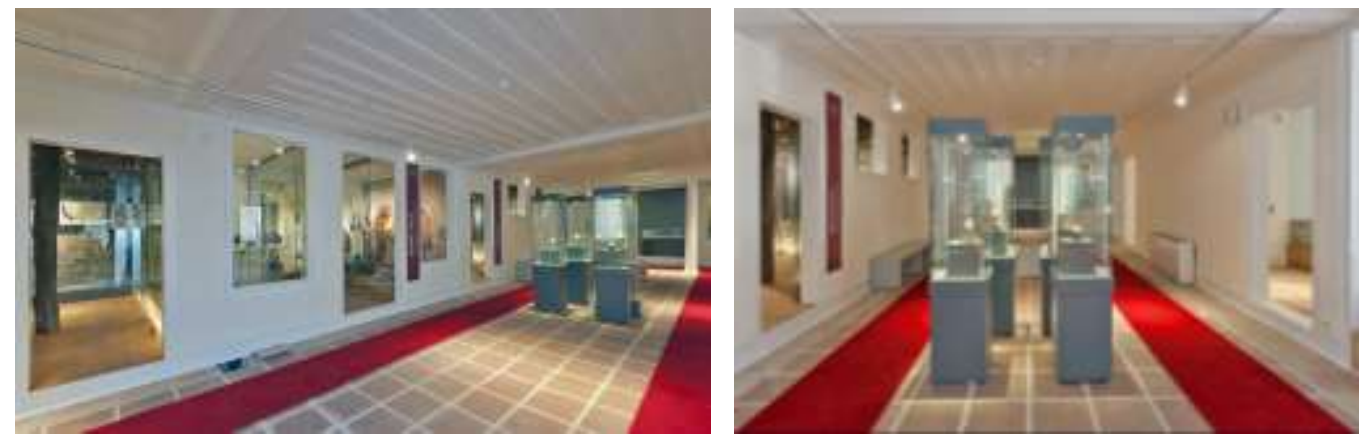

Şekil 42. Galata Mevlevihanesi İç Mekânı ve Sergi Bölümleri(URL3)

Şekil 43. Galata Mevlevihanesi İç Mekânı ve Sergi Bölümleri (URL3)

Galata Mevlevihane Müzesi sergi bölümlerinin, özellikle "Derviş odaları" bölümlerinde yer aldığı görülmektedir. Müze içinde, "Sufilik, Tarikatlar, Son Mevleviler" konuları ele alınmıştır. Müzede, solda yer alan ilk odada "buluntular", ikinci odada "teber, keşkülü fukara, mutteka, nefir 
ve tacı şerif gibi tarikat eşyaları", üçüncü odada "Matbah-1 Şerif", dördüncü odada "Mevlevi tarikatına ait giyim kuşam nesneleri” yer almaktadır. Ayrıca, Galata Mevlevihanesi'nin tarihsel gelişim süreci sergilenmektedir. Anıtsal bir yapı olan yapının kendisi ve yapım sistemi de Mevlevihane mimarisini ve kaybolan bir tarikatı tanıtması açısından önemli bir sanat eseridir.
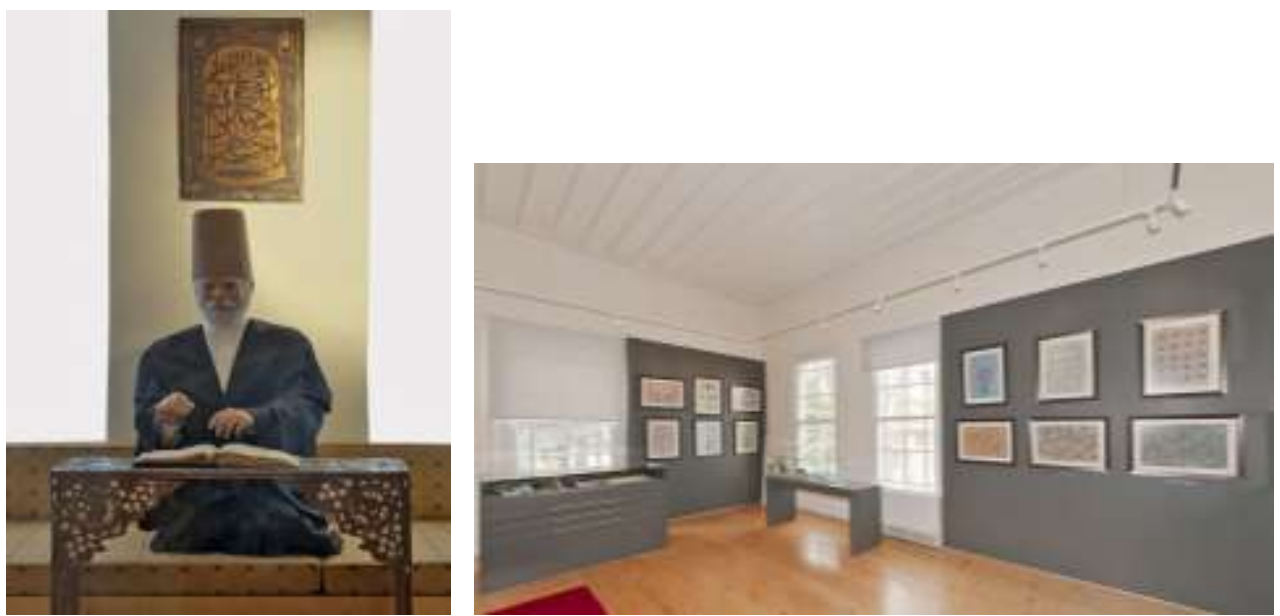

Şekil 44. Galata Mevlevihanesi Sergi bölümleri (URL3) Şekil 45. Galata Mevlevihanesi İç Mekânı ve Sergi Bölümleri (URL3)

Orta holün karşısında yer alan beşinci mekânda, Mesnevi bölümü, sağ tarafindaki odalarda ise Derviş bölümleri tanıtılmaktadır. Diğer mekânlarda sırasıyla, "Mevlevilik ve Edebiyat", "Mevlevilikte ibadet ve zikir", "Mevlevilik ve Tekke Musikisi", "Mevlevilik ve Güzel Sanatlar" ve son bölümde "Son Mevleviler" konuları anlatılmaktadır. Onuncu bölümde ise, Mevlevi Dedesi önünde bir semazen figürünün görüleceği hologram gösterisi sergilenmektedir.

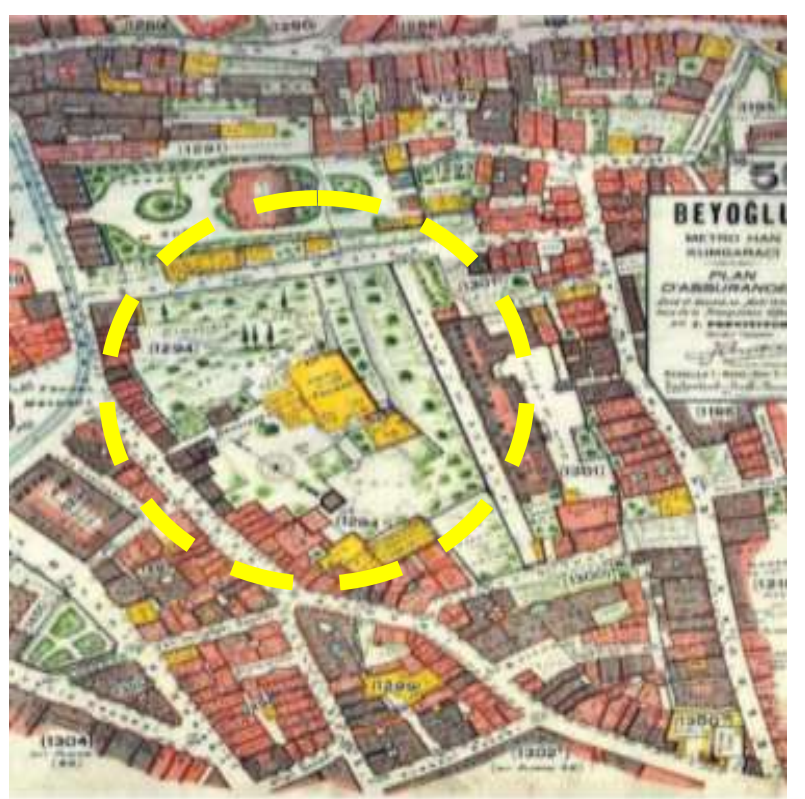

Şekil 46. Pervetitch Haritası, (50 Numaralı Galata Mevlevihanesi paftası 1932 yılında çizilmiştir) (Özdemir, 2018) 

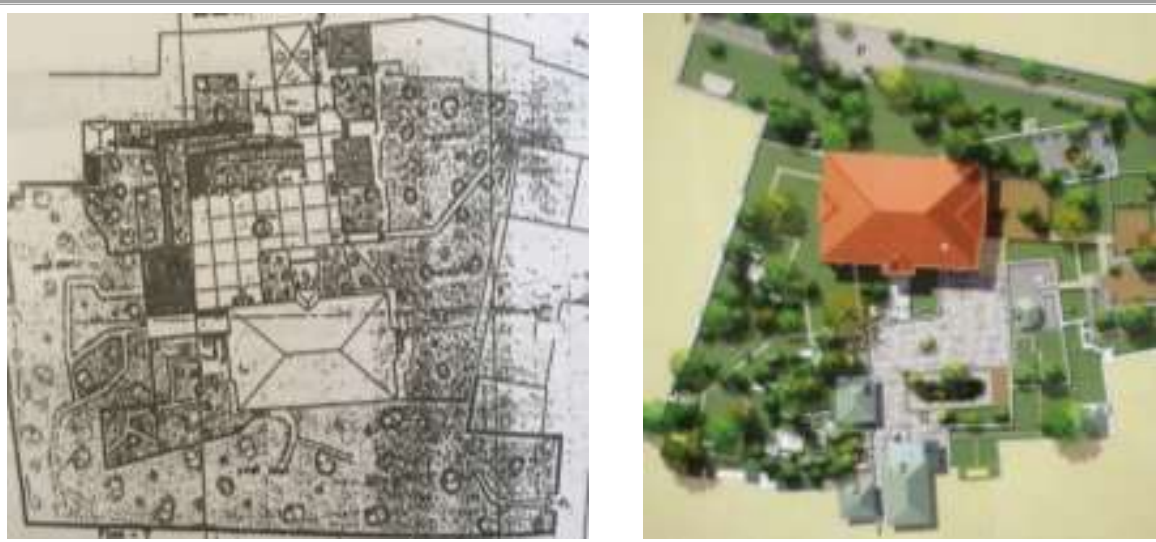

Şekil 47. Galata Mevlevihanesi Vaziyet Planı, İstanbul (Dayığlu, 2003) Şekil 48. Galata Mevlevihanesi Vaziyet Planı ve yerleşim planı, İstanbul (URL4)
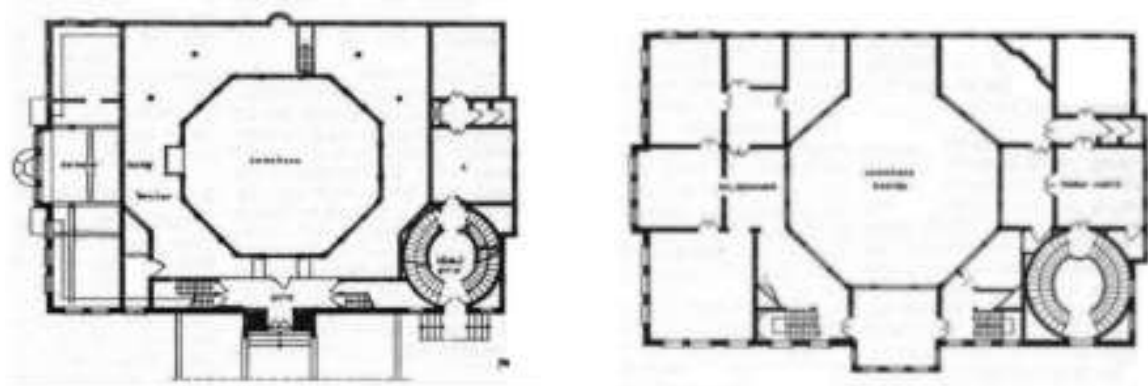

Şekil 49. Galata Mevlevihanesi Zemin kat planı Şekil 50. Galata Mevlevihanesi Üst kat plan (Dayıoğlu, 2003)
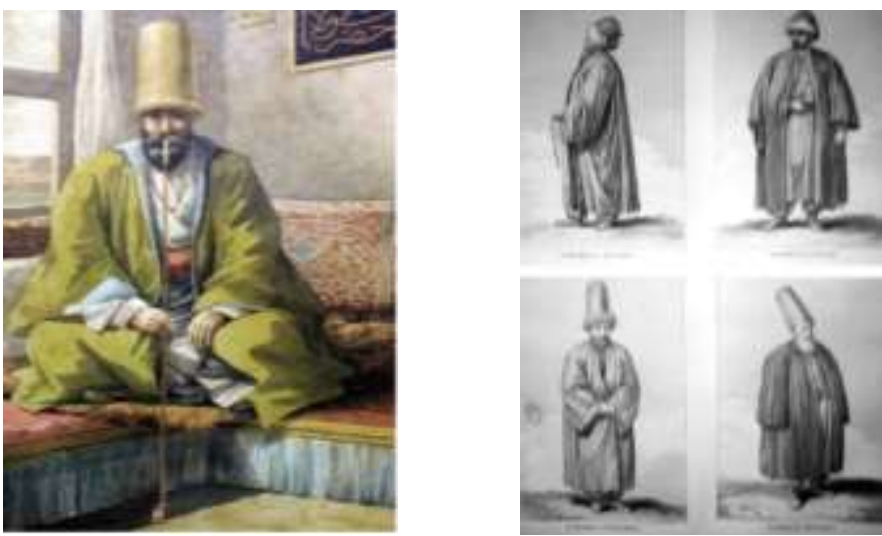

Şekil 51. Mevlevi Dedesi Şekil 52. Mevlevi ve Rufai Derviş ve şeyh kıyafetleri

(Özdemir, 2018)

\section{Manisa, Galata ve Lefkoșa Mevlevihaneleri Örnekleri*}

14 ve 16. yüzyıl aralıklarında inşa edilen ve çok kereler onarım gören bu yapılar, gerek mimari özellikleri, gerekse kaybolmuş bir tarikatın somut örnekleri olması açısından, korunması gerekli yapılardır. Yapıların, genel olarak bu yüzyıllarda, taş yığma inşa sisteminde yapılmaları sebebiyle, bu sistemde inşa edildiği görülür. Kıbrıs'ta yer alan mevlevihanenin tek katlı, Manisa'da yer alan mevlevihanenin iki katlı, İstanbul'da yer alan mevlevihanenin ise üç katlı olduğu

* Makalenin bir kısmı, 26-28 Ekim 2017 tarihlerinde Uluslararası Manisa Sempozyumunda (Manisa) sunulmuştur. Makale yeniden ele alınarak hazırlanmıştır. 
görülmektedir. Yapıların, kentsel olarak yoğun olan bölgelerde çok katlı, az yoğun olan bölgelerde ise tek katlı olduğu görülmektedir. Galata Mevlevihanesi'nin farklı olarak ahşap- karkas olarak inşa edildiği söylenebilir. Bu yapıda görülen ahşap mimari özellikler, İstanbul konut mimarisinin genel karakterini taşımaktadır.

Tablo 1: Lefkoşa Mevlevihanesi, Manisa Mevlevihanesi, Galata Mevlevihanesi’nin karşılaştırmalı analizi

\begin{tabular}{|c|c|c|c|}
\hline YAPI ADI & YAPIM YILI/YAPTIRAN & MIMMARI ÖZELLÍKLERİ & PLAN ŞEMASI \\
\hline $\begin{array}{l}\text { LEFKOŞA } \\
\text { MEVLEVİ } \\
\text { HANESI, } \\
\text { (KKTC) }\end{array}$ & $\begin{array}{l}\text { Arap Ahmed Paşa } \\
\text { 1002/1593-1594 } \\
\text { yaptırıldı. }\end{array}$ & $\begin{array}{l}\text { Yapı tek katlı ve yı̆ğma } \\
\text { sistemde inşa edilmiştir. } \\
\text { Avlunun doğusundaki basık } \\
\text { kemerli giriş kapısından } \\
\text { semahaneye } \\
\text { geçilmektedir. Bina içiünde, } \\
\text { mihrap, sema ayinlerinin } \\
\text { düzenlendiği bölüm, ahşap } \\
\text { mutrib mahfili ve bir mutfak } \\
\text { mekânları yer almaktadır. } \\
\text { Semahaneden, altı kubbeyle } \\
\text { örtülü olan türbe bölümüne } \\
\text { girilmektedir. }\end{array}$ & \\
\hline $\begin{array}{l}\text { MANISA } \\
\text { MEVLEVİ } \\
\text { HANESI }\end{array}$ & 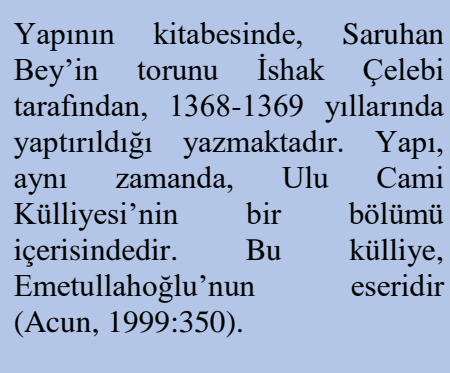 & $\begin{array}{l}\text { Yap1 iki katlı ve yığma } \\
\text { sistemde inşa edilmiştir Yap1 } \\
\text { ortada küçük bir kubbesi } \\
\text { bulunan düz çatılı bir binadır. } \\
\text { Yap1 ortasında semahanesi olan } \\
\text { dört eyvanlı plan şeması } \\
\text { düzenindedir. }\end{array}$ & \\
\hline $\begin{array}{l}\text { GALATA } \\
\text { MEVLEVI } \\
\text { HANESI, } \\
\text { İSTANBUL }\end{array}$ & $\begin{array}{l}\text { İskender Paşa tarafından } 1491 \\
\text { yılında kurulmuştur. } 1608 \text { yılında } \\
\text { kapsamlı bir onarım geçirmiştir. } \\
\text { 17. Yüzyılın ilk yarısında Tersane } \\
\text { ve Matbah Emini İsmâil Ağa } \\
\text { yapıda onarım çalışmaları } \\
\text { gerçekleştirmiştir. } 1765 \text { yılında } \\
\text { meydana gelen Tophane } \\
\text { yangınında yapı zarar görmüş, } 3 . \\
\text { Mustafa, yapıyı yeniden inşa } \\
\text { ettirmiştir. 3. 1791-92 yıllarında } \\
\text { mevlevîhâne yapılarında imar } \\
\text { hareketlerinde bulunmuştur. } 2 . \\
\text { Mahmud döneminde } 1819 \text { ve } \\
\text { 1835 tarihlerinde restore } \\
\text { edilmiştir. Sultan Abdulmecid } \\
\text { döneminde, 1851 - 1859 } \\
\text { yıllarında yapım, onarım ve } \\
\text { tamiratlar ile yapı son şeklini } \\
\text { almıştır (Tanman,1996). }\end{array}$ & $\begin{array}{l}\text { Semahane, ahşap bir konağı } \\
\text { anımsatan mimarisi ile diğer } \\
\text { Mevlevihane yapılarında } \\
\text { farklıdır.Semahane yapısı, Sema } \\
\text { alanı, alt katta derviş Odaları ile } \\
\text { üst kat mahfiller olmak üzere üç } \\
\text { katlı bir plandan oluşmaktadır. } \\
\text { Yapının sol bölümünde, Bacılar } \\
\text { Dairesi adı verilen Kadınlar } \\
\text { Maksuresi, üst katlarda ise } \\
\text { mahfiller yer almaktadır } \\
\text { (URL3) }\end{array}$ & \\
\hline
\end{tabular}


Yapılar plan şemaları yönüyle değerlendirildiğinde, Lefkoşa Mevlevihane'sinde yapı içinde türbe bölümlerinin olduğu, Manisa ve İstanbul Galata Mevlevihanesi'nde ise hazire bölümlerinin dışarıda yer aldığı görülmektedir. Yapıların semahaneleri Lefkoşa ve Manisa Mevlevihaneleri'nde daire planlı, Galata Mevlevihanesi'nde ise sekizgen planlı olarak inşa edilmiştir. Galata mevlevihanesinin kurulduğu tarihin 15. yüzyıl olmasına rağmen, çeşitli dönemlerde restore edilmesi ve onarım geçirmesi sebebi ile 17. yüzyıla ait mimari özellikler taşıdığı görülmektedir. Aynı zamanda, Galata Mevlevihanesi'nin, incelenen diğer mevlevihanelere göre daha karmaşık bir yapı olduğu, hünkara ve alt katta kadınlara ait bölümleri de içerdiği söylenebilir. Manisa Mevlevihanesi ise, diğer mevlevihanelerden farklı olarak, dervişlerin çile çekme hücrelerini plan şemasında içeren, özgün bir örnektir.

\section{Genel Değerlendirme ve Sonuç}

Özgün işlevini yitirmiş anıtsal yapıların yeniden işlevlendirilerek, kültürel bir varlık olarak yaşatılması, tarihi yapıların sürdürülerek kullanılması açısından önem taşımaktadır. Kültürel turizmin önem kazandığı günümüz koşullarında, tarihi yapıların yeniden işlevlendirilmesi, kentlere, hem ekonomik yönden, hem de tarihi kültürel kimliğin korunması yönünden katkıda bulunmaktadır. Bununla birlikte, yeniden işlevlendirme, hem anıtsal yapıların korunmasına, hem de kentlerin kimliklerinin sürdürülmesine olanak sağlamaktadır.

Mevcut kültürel mirasın yeniden işlevlendirilmesi, dünyada olduğu gibi ülkemizde de, uygulanması gerekli restorasyon yöntemidir. Tarihi değer taşıyan kültür varlıklarının zaman içinde özgün işlevini kaybetmesi, kentsel anlamda, imar alanında uğradıkları değişiklikler ve ekonomik etkenler, yapıların yeniden işlevlendirilmesini gerektirmektedir. Yeniden işlevlendirerek kullanımın, sosyal, kültürel, ekonomik ve sürdürülebilirlik anlamında olumlu katkıları vardır. Geçmişten günümüze kalan birçok anıtsal yapı, mevcut yapıların eskimesi, sosyal hayattaki değişim, teknolojik gelişmeler, kentsel gelişme ve düzenlemeler sebebiyle kullanılmaz olmuştur. Bununla birlikte, zamanla eskimenin ve kullanılmamanın verdiği tahribatlarla yapılar bozulmaktadır.

Yapıların işlevlendirilerek restore edilmesi, hem topluma kazandırılmasını, hem de bakım ve onarımının yapılarak sürdürülebilmesini sağlayacaktır. Özellikle tarihi ve kültürel önem taşıyan anıtsal yapıların yeniden işlevlendirilmesi, bu yapıların günümüzde de kullanımını mümkün kılmaktadır. Ancak, tarihi yapıların özellikle anıtsal yapıların yeniden işlevlendirilmesinde, yapıya verilecek yeni işlevlerin, yapının özgün niteliklerine zarar vermeyecek, hatta sanat eseri özelliklerini vurgulayacak şekilde planlanması gerekmektedir. Zira pek çok anısal yapının, restorasyonlardan sonra, uygun işlevlerle kullanılmadıkları için (örneğin Anadolu'da yer alan ve restore edilen pek çok kilise yada hamamlar) ziyaretçisi çok az olmakta yada olmamaktadır. Yada bu yapılar özgün özelliklerini sergileyememektedir.

Kültürel varlıkların yeniden işlevlendirilmesinde uygun işlevlerin uygulanması için, hem kentsel, hem de yapıya yönelik araştırmaların yapılması gerekmektedir. Özellikle özgün işleviyle kullanılamayan anıtsal yapılara yeni işlevler verilirken, yapının mevcut özellikleri kaybedilmemelidir. Tarihi yapıların sürdürülebilir ve yaşanabilir korunması için yapının değerini koruyarak, vurgulayacak, aynı zamanda günümüz koşullarında yaşatabilecek kararlar alınmalıdır. Mevlevihane ve vb. gibi anıtsal yapılarda; yapı iç mekânlarının kendi dönem özelliklerini yansıtacak şekilde tasarlanması, kendi dönemine ait objelerin sergilenmesi ve yapının içine mimarisini tanıtacak bilgi levhalarının yerleştirilmesi önemlidir. Böylelikle anıtsal yapının ve iç mekânlarının özgünlüğünün korunması, sürdürülmesi sağlanabilir.

Sonuç olarak, anıtsal yapıları korunması ve sürdürülmesi gerekli "sanat eserleri"dir. Anıtsal yapıların yeniden işlevlendirilmesi, etkili ve sürekli korumaya destek olmaktadır. Bu işlevlendirmeler, yapının özgün halini bozmayacak, yapı kimliğine zarar vermeyecek, tasarım ve iç mekân mobilyalarıyla yapının karakterini zedelemeyecek şekilde planlamalıdır. İncelenen 
Mevlevihane örneklerinde olduğu gibi, anıtsal yapıların yeniden işlevlendirilerek kullanıma açılması gerekmektedir. Yeniden işlevlendirmede, yapıların özgün fonksiyonu ile kullanılamadığı durumlarda, döneminin özelliklerini yansıtacak "müze" olarak kullanımı desteklenebilir. Bu işlev, yapıya en az müdahale gerektirecek, kullanım modeli olabilir. Ayrıca, daha önce de belirtildiği gibi, anıtsal yapılar bir sanat eseridir. Bu sebeple, öncelikli olarak, Mevlevihane ve vb. gibi anıtsal yapılarda; "kitlesel bütünlük ve iç mekân özellikleri" vurgulanmalı ve tanıtılmalıdır. Bu yönde işlevler önerilmeli, mümkünse kaybolan Mevlevi tarikatının özelliklerini sergileyecek müze işlevi önerilmelidir.

\section{Kaynakça}

Ahunbay, Z. (1996), Tarihi Çevre Koruma ve Restorasyon, Yem yayınları.

Acun, H.İ., (1999), Manisa'da Türk Devri Yapıları, Türk Tarih Kurumu, VI.Dizi- Sayı 56, s.350368. Acun

Altan, M. H., (2001), Kıbrıs'ta Türk Malları, C. II, Kastaş Yay..

Atalan, Ö., (2017), Geçmişten Günümüze Manisa Şehzade 2. Mehmed ve Manisa Tarihi, Kültürü, Ekonomisi, Cilt3, Manisa Celal Bayar Üniversitesi Rektörlük Basımevi.

Dayığlu, S., (2003), Galata Mevlevihanesi, Yeni Avrasya.

Demiraslan, D., (2014). "Mekân Tasarım Özellikleri Açısından Gelibolu Mevlevihanesi”, Türk Kültürü Ve Haci Bektaş Velî Araştirma Dergisi, 72, 43-67.

Emecen, M. F., (2006), Tarihin Içinde Manisa, Manisa Belediyesi Kültür Yayınları.

Çelebi, E., (1935), Evliya Çelebi Seyahatnamesi, 9 cilt, Anadolu, Suriye, Hicaz (1671-1672), İstanbul.

Fedai, H., (2010), "Lefkoşa Mevlevîhânesi”, İkinci Uluslararası Mevlânâ, Mesnevî ve Mevlevîhâneler Sempozyumu Bildirileri, Celal Bayar Üniversitesi Manisa Yöresi Türk Tarih ve Kültürünü Araştırma ve Uygulama Merkezi.

Gökalp, K., (2010), "Dünyada Mevlâna İzleri Bakışında Kıbrıs'ta Mevlevîlik Geçmiş ve Şimdi”,Sümam Yayınları: 5 / Bildiriler Serisi: 2, s.212.

Gökmen, E., (2014) Manisa Mevlevîhânesi Şeyhi Mehmed Bahâeddin Efendi'nin Terekesi (1771). "Sûfí Araştırmaları", 5(9), 1-62.

Kaya, B.A., (2017), "Lefkoşa Mevlevîhânesi'nin Şair Şeyhlerinden Siyâhî Mustafa Dede”, Kıbrıs Araştırmalart ve İncelemeleri Dergisi, I/1, ss. 15-38, http://www.kaid.kisbu.edu.tr.

Köklü, N., (1984), Saruhanoğulları Beyliği Devrinde Manisa, Manisa Dergisi, sayı 7, Nisan , s. 622, Manisa .

Kuban, D., (2000), Tarihi Çevre Korumanın Mimarlık Boyutu, Yem Yayın.

Manisa Mevlevihanesi , IX. Vakıf Haftası Kitabı (Aralık 1991-basım 1992) 109- 124.

Numan, İ., (2002) 1. Uluslararası Mevlana, Mesnevi ve Mevlevihaneler Sempozyumu Bildirileri, (19- 21 Aralık 2002- Manisa Mevlevihanesi), Celal Bayar Üniversitesi Manisa Yöresi Türk Tarihi ve Kültürünü Araştırma ve Uygulama Merkezi, s. 265.

Özdemir, Y., (2018). Galata Mevlevihanesi Müzesi (Editör: Doç. Dr. Süleyman Berk), Türkiye Turing ve Otomobil Kurumu, Acar Matbaa.

Özönder, H., (2010), "Kıbris'ta Mevlevilik ve Mevlevihaneler”, 6. Millî Mevlana Kongresi, Tebliğler”, Selçuk Üniversitesi Yayını, 22-24 Mayıs Konya 1992, S. 100; 
Pakalın, M. Z.,(1983), Osmanlı Tarih Deyimleri ve Terimleri Sözlüğü, c.2, s. 515.

Tezcan, N., (1994), Journal of the Ottoman Studies 14, Manisa Mevlevihanesi.

Tanman, B., (1996), Galata Mevlevihanesi, Islam Ansiklopedisi, https://islamansiklopedisi.org.tr/galata-Mevlevihanesi

Tanrıkorur, Ş.B., (1995) Manisa Mevlevihanesinin Restorasyonu, İstanbul Fetih Cemiyeti, Özal Matbaasi.

Uluçay, Ç., Gökçen I., (1939), Manisa Tarihi,:Şekilli Ay Matbaası.

URL 1. http://www.erimsever.com/HzMevlana_Mevlevihaneler.htm\#0

URL 2. https://islamansiklopedisi.org.tr/lefkose-Mevlevihanesi

URL 3. http://muze.semazen.net/content.php?id=00084

URL 4. http://www.degisti.com/index.php/archives/22304

URL 5. http://muze.semazen.net/content.php?id=00101

URL 6. https://www.galataMevlevihanesimuzesi.gov.tr

URL 7. http://www.wikiwand.com/tr/Galata_Mevlevihanesi 